\title{
Coupled calcium and inorganic carbon uptake suggested by magnesium and sulfur incorporation in foraminiferal calcite
}

\author{
Inge van Dijk ${ }^{1,2}$, Christine Barras ${ }^{1}$, Lennart Jan de Nooijer ${ }^{2}$, Aurélia Mouret ${ }^{1}$, Esmee Geerken ${ }^{2}$, Shai Oron ${ }^{3}$, and \\ Gert-Jan Reichart ${ }^{2,4}$ \\ ${ }^{1}$ LPG UMR CNRS 6112, University of Angers, UFR Sciences, 2 bd Lavoisier 49045, Angers CEDEX 01, France \\ ${ }^{2}$ NIOZ Royal Institute for Sea Research, Department of Ocean Systems (OCS), and Utrecht University, \\ Postbus 59, 1790 AB Den Burg, the Netherlands \\ ${ }^{3}$ Charney School of Marine Sciences, University of Haifa, Haifa, Israel \\ ${ }^{4}$ Utrecht University, Faculty of Geosciences, Budapestlaan 4, 3584 CD Utrecht, the Netherlands
}

Correspondence: Inge van Dijk (inge.van.dijk@nioz.nl)

Received: 13 November 2018 - Discussion started: 12 December 2018

Revised: 25 April 2019 - Accepted: 26 April 2019 - Published: 20 May 2019

\begin{abstract}
Shell chemistry of foraminiferal carbonate proves to be useful in reconstructing past ocean conditions. A new addition to the proxy toolbox is the ratio of sulfur $(\mathrm{S})$ to calcium $(\mathrm{Ca})$ in foraminiferal shells, reflecting the ratio of $\mathrm{SO}_{4}^{2-}$ to $\mathrm{CO}_{3}^{2-}$ in seawater. When comparing species, the amount of $\mathrm{SO}_{4}^{2-}$ incorporated, and therefore the $\mathrm{S} / \mathrm{Ca}$ of the shell, increases with increasing magnesium $(\mathrm{Mg})$ content. The uptake of $\mathrm{SO}_{4}^{2-}$ in foraminiferal calcite is likely connected to carbon uptake, while the incorporation of $\mathrm{Mg}$ is more likely related to Ca uptake since this element substitutes for $\mathrm{Ca}$ in the crystal lattice. The relation between $\mathrm{S}$ and $\mathrm{Mg}$ incorporation in foraminiferal calcite therefore offers the opportunity to investigate the timing of processes involved in $\mathrm{Ca}$ and carbon uptake. To understand how foraminiferal $\mathrm{S} / \mathrm{Ca}$ is related to $\mathrm{Mg} / \mathrm{Ca}$, we analyzed the concentration and within-shell distribution of $\mathrm{S} / \mathrm{Ca}$ of three benthic species with different shell chemistry: Ammonia tepida, Bulimina marginata and Amphistegina lessonii. Furthermore, we investigated the link between $\mathrm{Mg} / \mathrm{Ca}$ and $\mathrm{S} / \mathrm{Ca}$ across species and the potential influence of temperature on foraminiferal $\mathrm{S} / \mathrm{Ca}$. We observed that $\mathrm{S} / \mathrm{Ca}$ is positively correlated with $\mathrm{Mg} / \mathrm{Ca}$ on a microscale within specimens, as well as between and within species. In contrast, when shell $\mathrm{Mg} / \mathrm{Ca}$ increases with temperature, foraminiferal $\mathrm{S} / \mathrm{Ca}$ values remain similar. We evaluate our findings in the light of previously proposed biomineralization models and abiological processes involved during calcite precipitation. Although all kinds of processes, including crystal lattice distortion and el-
\end{abstract}

ement speciation at the site of calcification, may contribute to changes in either the amount of S or Mg that is ultimately incorporated in foraminiferal calcite, these processes do not explain the covariation between $\mathrm{Mg} / \mathrm{Ca}$ and $\mathrm{S} / \mathrm{Ca}$ values within specimens and between species. We observe that groups of foraminifera with different calcification pathways, e.g., hyaline versus porcelaneous species, show characteristic values for $\mathrm{S} / \mathrm{Ca}$ and $\mathrm{Mg} / \mathrm{Ca}$, which might be linked to a different calcium and carbon uptake mechanism in porcelaneous and hyaline foraminifera. Whereas $\mathrm{Mg}$ incorporation might be controlled by $\mathrm{Ca}$ dilution at the site of calcification due to $\mathrm{Ca}$ pumping, $\mathrm{S}$ is linked to carbonate ion concentration via proton pumping. The fact that we observe a covariation of $S$ and $\mathrm{Mg}$ within specimens and between species suggests that proton pumping and $\mathrm{Ca}$ pumping are intrinsically coupled across multiple scales.

\section{Introduction}

The elemental and isotopic compositions of foraminiferal calcium carbonate shells reflect seawater chemistry and are therefore widely used to reconstruct specific marine environmental conditions. Besides the potential of $\mathrm{Mg} / \mathrm{Ca}$ and $\delta^{18} \mathrm{O}$ to reconstruct seawater temperature, currently available proxies permit reconstruction of part of the marine inorganic carbon system (Beerling and Royer, 2011; Hönisch and Hemming, 2005). One of the most recent additions to the 
proxy tool box is the sulfur to calcium ratio $(\mathrm{S} / \mathrm{Ca})$ values of foraminiferal shells. In both abiogenic and biogenic carbonates, sulfur is mainly present in the form of $\mathrm{SO}_{4}^{2-}$, where it substitutes for $\mathrm{CO}_{3}^{2-}$ (Pingitore et al., 1995; Perrin et al., 2017). S/Ca is correlated to the ratio of $\mathrm{SO}_{4}^{2-}$ and $\mathrm{CO}_{3}^{2-}$ in seawater in both inorganic carbonates (Fernández-Díaz et al., 2010) as well as in foraminiferal calcite (Paris et al., 2014; van Dijk et al., 2017a). However, the few calibrations of foraminifera currently available are for the species Amphistegina gibbosa and Sorites marginalis and show speciesspecific offsets: the amount of $\mathrm{SO}_{4}^{2-}$ incorporated, and therefore the $\mathrm{S} / \mathrm{Ca}$, increases with increasing $\mathrm{Mg}$ content (van Dijk et al., 2017a). Covariation of concentrations of $S$ and $\mathrm{Mg}$ across species could be due to increased incorporation of $\mathrm{SO}_{4}^{2-}$ over $\mathrm{CO}_{3}^{2-}$ as a response to elevated crystal lattice strain, due to higher concentrations of other elements, like Mg (Mucci and Morse, 1983; Evans et al., 2015), or since the ionic radius of $\mathrm{SO}_{4}^{2-}$ is larger than $\mathrm{CO}_{3}^{2-}$, it might indeed be possible that distortion of the lattice by $\mathrm{Mg}$ leads to substitution of $\mathrm{CO}_{3}^{2-}$ by $\mathrm{SO}_{4}^{2-}$. Another explanation would be cotransport of elements to the site of calcification (van Dijk et al., 2017b) or coupling of both $\mathrm{Mg}$ and $\mathrm{SO}_{4}^{2-}$ pathways during biomineralization. To understand species-specific effects and constrain the application of these proxy relationships, it is necessary to focus on understanding element incorporation in foraminiferal calcite during biomineralization, i.e., in this case apparent coupling of $\mathrm{Mg}$ and $\mathrm{S}$ uptake and incorporation into foraminiferal calcite. While incorporation of sulfur is likely related to carbon uptake, due to the relation between calcite $\mathrm{S} / \mathrm{Ca}$ and seawater $\mathrm{SO}_{4}^{2-} / \mathrm{CO}_{3}^{2-}$, foraminiferal $\mathrm{Mg} / \mathrm{Ca}$ more likely reflects processes related to Ca uptake or $\mathrm{Mg}$ transport. Therefore, studying the relation between these elements might provide insight into the processes involved and timing of uptake of elements during biomineralization.

Isotopic and element composition of the foraminiferal shell depends on the chemistry of the fluid at the site of calcification, which in turn depends on ambient seawater and element-specific partitioning, which in inorganic experiments is known to rely on precipitation rate (Mucci, 1987; Lorens, 1981). Foraminiferal species either create a smooth porcelaneous shell, relatively rich in magnesium (> $4 \mathrm{wt} \% \mathrm{Mg}$ ), or perforate hyaline shells, by supposedly contrasting calcification pathways (e.g., Hemleben et al., 1986; de Nooijer et al., 2009). In perforate hyaline species, studies have shown that the site of calcification is separated from the surrounding seawater by a protective envelope. Although observations for Ammonia suggest this envelope might not be closed at the start of calcification (Nagai et al., 2018), the carbonate chemistry at the site of calcification is proposed to be controlled by the foraminifer and, for example, characterized by a high internal and low external $\mathrm{pH}$ (de Nooijer et al., 2009; Glas et al., 2012; Toyofuku et al., 2017), as well as the chemistry of the calcification fluid itself (Erez, 2003; Bentov and Erez, 2006; Evans et al., 2018). Control- ling the physicochemical conditions at the site of calcification is necessary to overcome inhibition of calcite nucleation and growth by sulfate and magnesium ions (e.g., Zeebe and Sanyal, 2002; Fernández-Díaz et al., 2010; Reddy and Nancollas, 1976). Removal or unavailability of these ions is therefore part of several proposed biomineralization models (Bentov and Erez, 2006; Bentov et al., 2009), whereas inhibition can also be overcome by increasing the saturation state at the site of calcification without needing removal of ions that inhibit calcification (Zeebe and Sanyal, 2002; de Nooijer et al., 2009; Toyofuku et al., 2017).

Here we investigate the covariation between magnesium and sulfur content of different species of foraminifera to provide new constraints on biomineralization. At the microscale level this is done by analyzing the distribution of $\mathrm{S}$ and $\mathrm{Mg}$ within the shell wall and at the species level by comparing $\mathrm{S} / \mathrm{Ca}$ and $\mathrm{Mg} / \mathrm{Ca}$ of different species covering a wide taxonomic range, including different calcification pathways. Furthermore, we measured S/Ca values of shells of Amphistegina lessonii grown at different temperatures to investigate the potential effect of temperature on foraminiferal element incorporation. By changing seawater temperature, incorporation of $\mathrm{Mg}$ in many species of foraminifera increases (for an overview of different species: Toyofuku et al., 2011) due to the empirical positive relationship between temperature and $\mathrm{Mg} / \mathrm{Ca}$ in calcite (e.g., Nürnberg et al., 1996). We investigate the sulfur and magnesium incorporation in A. lessonii as a function of temperature, as to our knowledge a temperature$\mathrm{Mg}$ calibration is currently lacking for this species. All observations combined show how $\mathrm{Mg}$ and $\mathrm{S}$ are incorporated in foraminiferal calcite across multiple scales and thereby provide new insights on element uptake and transport during foraminiferal biomineralization.

\section{Methods and materials}

\subsection{Collection of foraminifera}

Coral debris was collected from Burgers' Zoo in Arnhem, the Netherlands, by scuba diving. The corals from the IndoPacific Ocean and coral debris are rich in a wide range of tropical foraminiferal species from this region (Ernst et al., 2011). The seawater in this aquarium is maintained at near-natural conditions (salinity, temperature and carbonate chemistry). Collected sediment was transported to the Royal Netherlands Institute of Sea Research (NIOZ) and stored in aerated small aquaria at room temperature. From this stock, living specimens of Amphistegina lessonii were collected from the coral debris for the culture experiment. Viable specimens of A. lessonii, recognized by color, attachment to coral debris and pseudopodial activity, were isolated and stored per 5-10 specimens in $70 \mathrm{~mL}$ petri dishes with $0.2 \mu \mathrm{m}$ filtered North Atlantic surface seawater (salinity $=35.2$ ) with the addition of $1 \mathrm{mLL}^{-1}$ trace metal $\mathrm{K}$ mix (Guillard and 
Ryther, 1962). Furthermore, from the foraminiferal stock, specimens of other foraminifera species with either hyaline (Heterostegina depressa - in addition to Amphistegina lessonii) or porcelaneous (Sorites orbiculus, Spiroloculina angulata, Spiroloculina communis, Quinqueloculina pseudoreticulata and Quinqueloculina sp.) shells were picked to study species-specific incorporation of sulfur and magnesium in foraminiferal calcite.

\subsection{Setup of controlled temperature experiment}

After asexual reproduction events of isolated specimens of A. lessonii (about one-third of the specimens reproduced), the four most numerous generations $(\sim 40-80$ specimens per reproduction event) of $\sim 2$ chambered juveniles were incubated in duplicate with $0.2 \mu \mathrm{m}$ filtered North Atlantic surface seawater in $70 \mathrm{~mL}$ tissue bottles with hydrophobic caps at three different experimental conditions, resulting in $\sim 15$ 25 incubated clones per condition. Tissue bottles containing foraminifera were placed in either one of three climate incubators, set to 21,26 and $29^{\circ} \mathrm{C}$. Using tissue bottles with hydrophobic caps minimizes the amount of evaporation compared to culturing petri dishes. Nevertheless, half of the culture medium was replaced every $3 \mathrm{~d}$, during which salinity was measured. Salinity never deviated more than 0.3 units from the stock value of 35.2. The temperature within each incubator was monitored every $11 \mathrm{~min}$ by a temperate logger (Traceable Logger-Trac, Maxi Thermal). The average temperature for the three different conditions was $21.2 \pm 0.7$, $26.3 \pm 0.3$ and $29.5 \pm 0.2{ }^{\circ} \mathrm{C}( \pm 1 \mathrm{SD})$. Shelves within each incubator were equipped with in-house designed and manufactured LED shelves (full spectrum) to provide uniform light (PAR) conditions in the incubators. The LED lights were controlled by a time controller and set to 300 PAR $(300 \mu \mathrm{mol}$ of photons $\mathrm{m}^{2} \mathrm{~s}^{-2}$; high light condition) for a $12 \mathrm{~h}-12 \mathrm{~h}$ daynight cycle.

\subsection{Foraminiferal calcite chemistry}

\subsubsection{Cleaning methods}

Groups of selected species of Burgers' Zoo stock and Amphistegina lessonii from the controlled temperature experiment were cleaned before analysis of their shell chemistry. Specimens were transferred to acid-cleaned $0.5 \mathrm{~mL}$ PP (Polypropylene) tubes (TreffLab). For cleaning, we followed an adapted version of the protocol by Barker et al. (2003), described in van Dijk et al. (2017b). In short, to each vial, $250 \mu \mathrm{L}$ of freshly prepared $1 \% \mathrm{H}_{2} \mathrm{O}_{2}$ (buffered with $0.5 \mathrm{M} \mathrm{NH}_{4} \mathrm{OH}$ ) was added to remove organic matter. The vials were heated for $10 \mathrm{~min}$ in a water bath at $95^{\circ} \mathrm{C}$ and placed in an ultrasonic bath $(80 \mathrm{kHz}, 50 \%$ power, degas function) for $30 \mathrm{~s}$, after which the oxidizing reagent was removed with three rinses with double deionized water. These steps (organic removal procedure by oxidation) were repeated twice. Foraminiferal samples were subsequently rinsed five times with ultrapure water and dried in a laminar flow cabinet. Specimens from Burgers' Zoo were set apart for analysis by sector field ICP-MS, while the specimens from the controlled temperature experiment as well as a small number of A. lessonii from the Burgers' Zoo stock were placed on stubs for analysis by laser ablation (Reichart et al., 2003).

\subsubsection{Single chamber measurements by LA-Q-ICP-MS}

Element concentrations of individual chambers of A. lessonii from the controlled temperature culture experiment as well as the Burgers' Zoo stock were measured by a laser ablation quadrupole inductively coupled mass spectrometer (LA-QICP-MS), similar as has been described in a number of previous studies (van Dijk et al., 2017b; Geerken et al., 2018). In short, using an ArF Excimer laser (Existar) with deep UV $193 \mathrm{~nm}$ wavelength and $<4 \mathrm{~ns}$ pulse duration (NWR193UC, New Wave Research), with a circular spot of $80 \mu \mathrm{m}$, a repetition rate of $6 \mathrm{~Hz}$ and an energy density of $\sim 1 \mathrm{~J} \mathrm{~cm}^{-2}$, individual chambers of foraminiferal shells were targeted. The resulting aerosol was transported from the helium environment in a dual-volume cell of $\sim 1 \mathrm{~cm}^{3}$ (New Wave, TV2), to a Q-ICP-MS (iCap, Thermo Scientific) on a helium flow $\left(700 \mathrm{~mL} \mathrm{~min}^{-1}\right)$. Before entering the torch, $400 \mathrm{~mL} \mathrm{~min}^{-1}$ Argon was added using a $10 \mathrm{~cm}$ smoothing device made inhouse. Nitrogen was not added to the carrier gas to enable accurate measurement of ${ }^{55} \mathrm{Mn}$. Other monitored masses include ${ }^{7} \mathrm{Li},{ }^{23} \mathrm{Na},{ }^{24} \mathrm{Mg},{ }^{25} \mathrm{Mg},{ }^{43} \mathrm{Ca},{ }^{44} \mathrm{Ca},{ }^{88} \mathrm{Sr}$, and ${ }^{137} \mathrm{Ba}$, with a total cycle time of $140 \mathrm{~ms}$. Calibration was performed against MACS-3, a pressed powder carbonate (synthetic calcium) standard, with ${ }^{43} \mathrm{Ca}$ as an internal standard. NIST (National Institute of Standards and Technology) SRM (Standard Reference Materials) 610 and 612 glass standards were measured in triplicate at the end of each series (energy density of $5 \pm 0.1 \mathrm{~J} \mathrm{~cm}^{-2}$ ). We choose MACS-3 as a calibration standard, since element composition approaches the foraminiferal values closer than that of NIST 610 or 612 and therefore aids a more robust calibration, even though the MACS-3 is slightly less homogeneous (see precisions listed in Table 1). Accuracy and precision per element, per standard are reported in Table 1.

In total, 441 chambers were measured; 142 ablations on 59 specimens for a temperature of $21.2^{\circ} \mathrm{C}, 189$ ablations on 63 specimens for $26.3^{\circ} \mathrm{C}$ and 110 ablations on 42 specimens for $T=29.5^{\circ} \mathrm{C}$. Element concentrations were calculated by integrating individual laser-ablation profiles using an adapted version of the data reduction software SILLS (Signal Integration for Laboratory Laser Systems; Guillong et al., 2008) package for MATLAB (Geerken et al., 2018; van Dijk et al., 2017b). Profiles were selected to avoid contamination of the outer or inner part of the foraminifera (for examples of profile selection see, e.g., Dueñas-Bohórquez et al., 2011; Mewes et al., 2014; van Dijk et al., 2017c). Average element/Ca $(E / \mathrm{Ca})$ per temperature conditions were calculated 
Table 1. Accuracy (RSD of $n$ measurements) and precision (\% of reference value) of three standards, including the calibration standard MACS-3.

\begin{tabular}{lr|rr|rr}
\hline Element & MACS-3 $(n=105)$ & \multicolumn{2}{|c|}{ NIST 610 $(n=21)$} & NIST 612 $(n=20)$ \\
\cline { 2 - 6 } & Precision (RSD, \%) & Precision (RSD, \%) & Accuracy (\%) & Precision (RSD, \%) & Accuracy (\%) \\
\hline${ }^{7} \mathrm{Li}$ & 5 & 1 & NA & 4 & NA \\
${ }^{23} \mathrm{Na}$ & 5 & 6 & 106.9 & 6 & 108.0 \\
${ }^{24} \mathrm{Mg}$ & 3 & 1 & 106.4 & 5 & 90.6 \\
${ }^{25} \mathrm{Mg}$ & 3 & 2 & 106.0 & 5 & 90.2 \\
${ }^{55} \mathrm{Mn}$ & 3 & 1 & 101.0 & 2 & 101.7 \\
${ }^{88} \mathrm{Sr}$ & 3 & 2 & 100.0 & 2 & 102.5 \\
${ }^{137} \mathrm{Ba}$ & 3 & 3 & NA & 2 & NA \\
\hline
\end{tabular}

NA - not available

after removal of outliers (based on 1.5 - interquartile range). We applied a $t$ test to assess if $E / \mathrm{Ca}$ is different between temperature conditions using a bilateral test.

\subsubsection{Bulk measurements by SF-ICP-MS}

Grouped foraminifera from the controlled temperature experiment and the species from Burgers' Zoo stock (Amphistegina lessonii, Heterostegina depressa, Sorites orbiculus, Spiroloculina angulata, Spiroloculina communis, Quinqueloculina pseudoreticulata and Quinqueloculina sp.) were analyzed for the sulfur content in their shells. Foraminifera from the controlled temperature experiment received an additional cleaning step (following the same procedure as van Dijk et al., 2017a), since they were previously fixed on a laser ablation stub with tape. These specimens were transferred in groups of $\sim 10$ individuals to $0.5 \mathrm{~mL}$ acid-cleaned TreffLab PCR tubes and rinsed three times with $750 \mu \mathrm{L}$ of deionized water, during which the vials were transferred to the ultrasonic bath for $1 \mathrm{~min}(80 \mathrm{kHz}, 50 \%$ power, degas function). Subsequently, the samples were again placed in the ultrasonic bath for another minute after the addition of $750 \mu \mathrm{L}$ of Suprapur methanol (Aristar). The solvent was removed and the samples were rinsed three times with ultrapure water. Vials were dried in a laminar flow cabinet.

Samples from the temperature experiment and from the Burgers' Zoo were measured on different occasions, using a slightly different analytical approach. Both groups of samples were measured on an Element-2 (Thermo scientific) sector field double-focusing inductively coupled mass spectrometer (SF-ICP-MS). For the samples of the temperature experiment, $150 \mu \mathrm{L}$ of ultrapure $0.05 \mathrm{M} \mathrm{HNO}_{3}$ (PlasmaPURE) was added to each vial to dissolve all foraminiferal calcite. A $5 \mathrm{~s}$ pre-scan for ${ }^{43} \mathrm{Ca}$ was performed on the SF-ICP-MS to determine the $[\mathrm{Ca}]$ in the dissolved foraminiferal calcite solutions and according to these results, samples were diluted to obtain a solution with $40 \mathrm{ppm} \mathrm{Ca}$. After the cones were preconditioned over $2 \mathrm{~h}$ with $40 \mathrm{ppm}$ pure $\mathrm{CaCO}_{3}$, the final solutions were measured again for $\sim 170$ s per sample. Samples were injected into the ICP-MS using a microFAST MC system of Elemental Scientific (ESI) with a loop of $250 \mathrm{~mm}$ and a flow rate of $50 \mathrm{~mL} \mathrm{~min}^{-1}$. For the sample set of the temperature experiment, masses ${ }^{23} \mathrm{Na},{ }^{24} \mathrm{Mg},{ }^{32} \mathrm{~S},{ }^{34} \mathrm{~S}$ and ${ }^{43} \mathrm{Ca}$ were analyzed in medium resolution to separate ${ }^{16} \mathrm{O}^{16} \mathrm{O}$ from the ${ }^{32} \mathrm{~S}$ peaks and ${ }^{18} \mathrm{O}^{16} \mathrm{O}$ from the ${ }^{34} \mathrm{~S}$ peaks.

The samples from Burgers' Zoo were dissolved in $0.5 \mathrm{~mL}$ $0.1 \mathrm{MHNO}_{3}$ and diluted to $100 \mathrm{ppm} \mathrm{Ca}$ accordingly to the results of the $\mathrm{Ca}$ pre-scan. Elemental composition of the foraminifera was measured for a wide range of elements, including ${ }^{23} \mathrm{Na},{ }^{24} \mathrm{Mg},{ }^{32} \mathrm{~S},{ }^{34} \mathrm{~S}$ and ${ }^{43} \mathrm{Ca}$ at medium resolution. In total 46 isotopes were measured during $6 \mathrm{~min}$ at low resolution, $4 \mathrm{~min}$ at medium resolution and $1 \mathrm{~min}$ at high resolution with a $300 \mathrm{~mL} \mathrm{~min}^{-1}$ flow rate using a peristaltic pump.

For both sets of measurements, samples were measured against six ratio calibration standards with a matching matrix, i.e., $40 \mathrm{ppm} \mathrm{Ca}$ for the temperature set and $100 \mathrm{ppm} \mathrm{Ca}$ for the Burgers' Zoo set. In addition to the foraminiferal samples, we measured several standards, including NFHS-1 (NIOZ Foraminifera House Standard; for details see Mezger et al., 2016), JCt-1 (Giant Clam, Tridacna gigas) and JCp1 (coral, Porites sp.; Okai et al., 2002) to monitor drift and the quality of the analyses. One of the ratio calibration standards was measured after every fifth sample to monitor drift. Accuracy of $\mathrm{Mg} / \mathrm{Ca}$ is $105 \%$ and $101 \%$ for JCt- 1 and $\mathrm{JCp}-$ 1 , respectively, with an external precision of $0.4 \%$ for both standards. Only JCp-1 has a certified value for $\mathrm{S} / \mathrm{Ca}$, and accuracy for our measurements is $94 \%$ based on this standard. The external precision of $\mathrm{S} / \mathrm{Ca}$ is $1.7 \%$ and $1.0 \%$ for $\mathrm{JCt}-1$ and $\mathrm{JCp}-1$. We used a ratio calibration method (de Villiers et al., 2002) to calculate foraminiferal $\mathrm{S} / \mathrm{Ca}\left(\mathrm{mmol} \mathrm{mol}^{-1}\right)$.

\subsubsection{Shell wall variability by electron probe microanalysis}

Specimens of various foraminiferal species (Ammonia tepida, Bulimina marginata) from a recently published culture study (Barras et al., 2018) and Amphistegina lessonii cultured in the same culture setup were prepared for electron 
probe microanalysis (EPMA) to investigate the intra-shell incorporation of sulfur and magnesium. These foraminifera were cultured under hypoxia (30\% oxygen saturation) in controlled stable conditions and previously studied to investigate the $\mathrm{Mn}$ incorporation in foraminiferal calcite (for details and culture methodology see Barras et al., 2018). Ammonia tepida and Bulimina marginata were cultured at $12^{\circ} \mathrm{C}$, while specimens of Amphistegina lessonii were grown at $25^{\circ} \mathrm{C}$. For the latter species, the setup was equipped with a light system with $12 \mathrm{~h}-12 \mathrm{~h}$ light cycle.

Specimens of each species were embedded under vacuum in resin (2020 Araldite $^{\circledR}$ resin by Huntsman International LLC) using $2.5 \mathrm{~cm}$ epoxy plugs. Samples were polished using increasingly fine sanding paper. In the final polishing step, a diamond suspension with grains of $0.04 \mu \mathrm{m}$ was used, resulting in exposure of a cross section of the chamber walls. After applying a carbon coating, the samples were placed in the microprobe sample holder. After selection of target areas, several small high-resolution maps $(130 \times 97$ pixels $)$ were analyzed at $12.0 \mathrm{kV}$ in beam scan mode for different elements (Ca, Mn, Mg, S and Na) with a dwell time of $350 \mathrm{~ms}$. In total, we analyzed 12, 8 and 9 chambers of 6, 4 and 6 specimens of Ammonia tepida, Bulimina marginata and Amphistegina lessonii, respectively, an overview of the number of maps per species and the location of the maps and transects can be found in the Supplement, Table S1 and in Figs. S1-S3.

All EPMA data were further processed using MATLAB, following similar protocols used by van Dijk et al. (2017a) and Geerken et al. (2018). In summary, pores and resin were excluded from the final maps by excluding areas where $\mathrm{Ca}$ levels were below a certain level (mostly around $<10000$ counts). The resulting concentration (level) maps were converted to semiquantitative $E / C a_{\text {EPMA }}$ by applying a calibration based on mineral standards (diopside for $\mathrm{Ca}$, tephroite for $\mathrm{Mn}$, forsterite for $\mathrm{Mg}$, celestine for $\mathrm{S}$ and jadeite for $\mathrm{Na}$ ). We choose to report these ratios as $E / C a_{\mathrm{EPMA}}$ to distinguish this data from quantitative data obtained by, e.g., LA-Q-ICP-MS and SF-ICP-MS. Mn, Mg, S and Na matrices were divided by the Ca matrix, to allow for a semiquantification of the counts to concentrations to obtain $E / C a$ EPMA $\left(\mathrm{mmol} \mathrm{mol}{ }^{-1}\right)$ maps.

For all successful EPMA maps, i.e., high-quality maps without distortion or charging during measurement, several rectangular areas perpendicular to the chamber wall (Fig. 1) were selected, hereafter called transect maps. In total we created 23, 15 and 16 transect maps for A. tepida, B. marginata and $A$. lessonii, respectively. From these transect maps, the average $\mathrm{Mg} / \mathrm{Ca}$ EPMA and $\mathrm{S} / \mathrm{Ca}$ EPMA values per column over the transect are plotted, resulting in a spatial distribution profile (Fig. 1d). The average values per column are plotted, to investigate the covariation of $\mathrm{S} / \mathrm{Ca}$ and $\mathrm{Mg} / \mathrm{Ca}$ in the foraminiferal chamber wall (Fig. 1c; S/CaEPMA versus $\mathrm{Mg} / \mathrm{Ca}$ EPMA).

For further analysis of peak and base values, only one transect per EPMA map is considered, to avoid overrepre- sentation of one chamber. The locations of these transects can be found in Fig. S1, S2 and S3 for specimens of Ammonia tepida, Bulimina marginata and Amphistegina lessonii, respectively. This resulted in 12, 8 and 9 distribution profiles from transect maps of individual chambers with for $A$. tepida, B. marginata and A. lessonii, respectively. For the resulting distribution profiles, we calculated and compared the average values of the maximum (high-concentration bands; $E / \mathrm{Ca}_{\mathrm{MAX}}$ ) and minimum (low-concentration areas; $\left.E / \mathrm{Ca}_{\mathrm{MIN}}\right)$ of the first peak, which is related to the primary organic sheet. The offset between maximum and minimum value $(\Delta \max -\min$; Fig. 2$)$ is calculated as absolute concentration difference $\left(E / \mathrm{Ca}_{\mathrm{MAX}}-E / \mathrm{Ca}_{\mathrm{MIN}}\right.$ in $\left.\mathrm{mmol} \mathrm{mol}{ }^{-1}\right)$ and expressed as a peak factor $\left(E / \mathrm{Ca}_{\mathrm{MAX}} / E / \mathrm{Ca}_{\mathrm{MIN}}\right)$. This allows for comparison of maximum (band) and minimum (non-band) values of $E / C a$ between the three species.

\section{Results}

\section{1 $\mathrm{S} / \mathrm{Ca}$ and $\mathrm{Mg} / \mathrm{Ca}$ of Amphistegina lessonii from controlled temperature conditions}

$\mathrm{S} / \mathrm{Ca}$ of A. lessonii cultured at $21.2-29.5^{\circ} \mathrm{C}$ is on average $1.48 \mathrm{mmol} \mathrm{mol}^{-1}$, with no trend with increasing temperature. $\mathrm{Mg} / \mathrm{Ca}$ increases with temperature, and LA and SF-ICPMS measurements are in good agreement. Based on the SFICP-MS data $\mathrm{Mg} / \mathrm{Ca}$ are on average $19.7 \mathrm{mmol} \mathrm{mol}^{-1}$ for $21.2^{\circ} \mathrm{C}, 25.5 \mathrm{mmol} \mathrm{mol}^{-1}$ for $26.3^{\circ} \mathrm{C}$ and $34.8 \mathrm{mmol} \mathrm{mol}^{-1}$ for $29.5^{\circ} \mathrm{C}$ (Fig. 3). Due to the number of datapoints, the relationship can be described with both a linear regression $\left(\mathrm{Mg} / \mathrm{Ca} \mathrm{CALCITE}=1.83 \cdot T-20.5, R^{2}=0.88\right)$ or an exponential regression $\left(\mathrm{Mg} / \mathrm{Ca}_{\mathrm{CALCITE}}=4.4767 e^{0.0683 \cdot T}, R^{2}=\right.$ 0.92). For LA-ICP-MS (Fig. S4 and Table S2) average values of $\mathrm{Mg} / \mathrm{Ca}$ are $20.5 \pm 5.7 \mathrm{mmol} \mathrm{mol}^{-1}$ for $21.2^{\circ} \mathrm{C}, 24.9 \pm 4.4$ for $26.3^{\circ} \mathrm{C}$ and $35.4 \pm 8.1 \mathrm{mmol} \mathrm{mol}^{-1}$ for $29.5^{\circ} \mathrm{C}$, which is 97.2, 102.4 and $98.4 \%$ compared to the SF-ICP-MS data. Thus, $\mathrm{Mg} / \mathrm{Ca}$ increases by $1.8 \mathrm{mmol} \mathrm{mol}{ }^{-1} \mathrm{per}^{\circ} \mathrm{C}$ in our studied temperature range. Element to calcium ratio of other elements, $\mathrm{Na} / \mathrm{Ca}, \mathrm{Sr} / \mathrm{Ca}$ and $\mathrm{Mn} / \mathrm{Ca}$, are presented in the Supplement (Fig. S1 and Table S2).

\subsection{S/Ca of foraminiferal species from an Indo-Pacific aquarium}

Average values of $\mathrm{S} / \mathrm{Ca}$ and $\mathrm{Mg} / \mathrm{Ca}$ per species collected from the Burgers' Zoo aquarium, including values of $A$. lessonii from the controlled temperature experiment, are presented in Fig. 4 and Table S3. For porcelaneous species, $\mathrm{Mg} / \mathrm{Ca}$ and $\mathrm{S} / \mathrm{Ca}$ are on average $148.9 \pm 14.9$ and $9.4 \pm$ $1.2 \mathrm{mmol} \mathrm{mol}^{-1}$, respectively, while hyaline species cover broader ranges, with $\mathrm{Mg} / \mathrm{Ca}$ from $36.8-153.3 \mathrm{mmol} \mathrm{mol}^{-1}$ and $\mathrm{S} / \mathrm{Ca}$ between 2.2 and $8.4 \mathrm{mmol} \mathrm{mol}^{-1}$. 

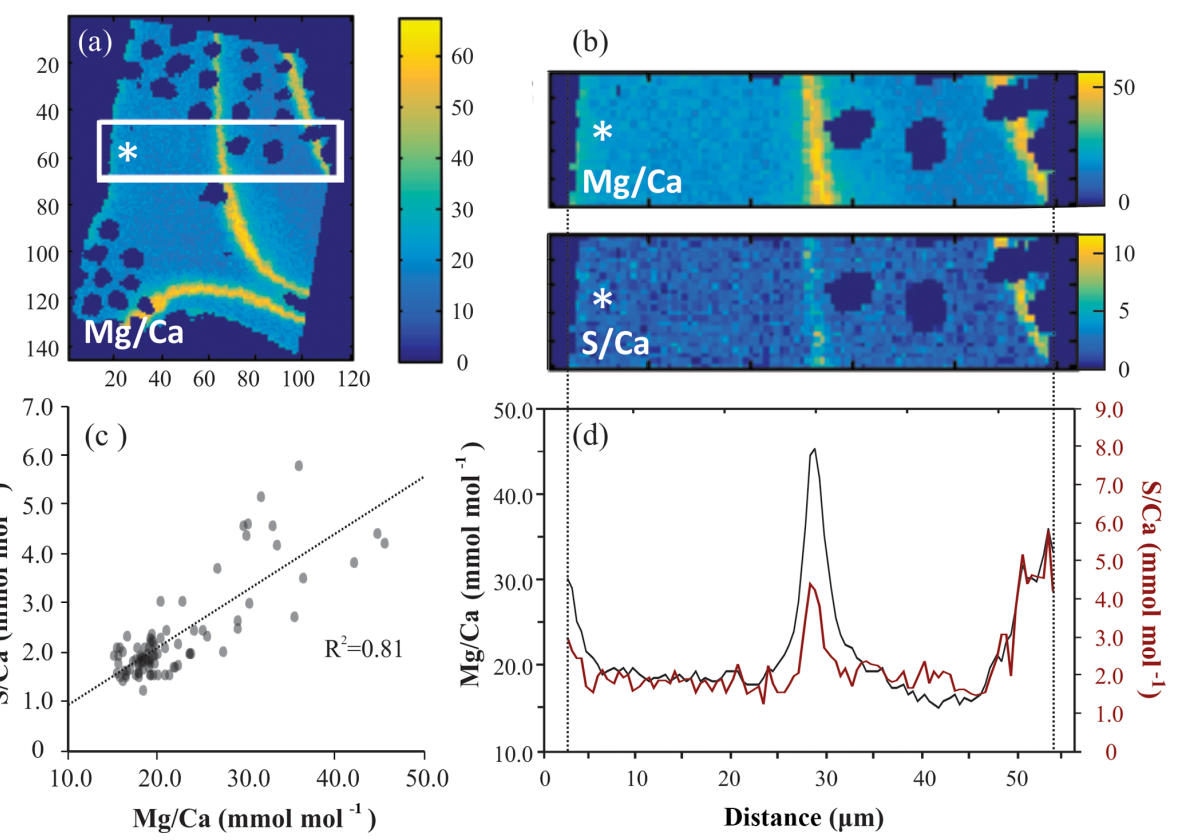

Figure 1. Example of EPMA data treatment from Amphistegina lessonii (top left specimen in Fig. S3): (a) general overview of Mg/CaEPMA map with transect selection; (b) selection of the map from (a) to isolate a transect of $\mathrm{Mg} / \mathrm{Ca}$ EPMA (top) and S/CaEPMA (bottom); (c) average $\mathrm{S} / \mathrm{Ca}$ EPMA and $\mathrm{Mg} / \mathrm{Ca}$ EPMA values plotted per column with the $R^{2}$ for the regression analysis; (d) average $E /$ CaEPMA of transect $\mathrm{Mg} / \mathrm{Ca} \mathrm{EPMA}_{\mathrm{A}}$ in black, S/CaEPMA in red. Asterisks indicate the outer side of the foraminiferal shell. Color scale is "parula" provided by the software.

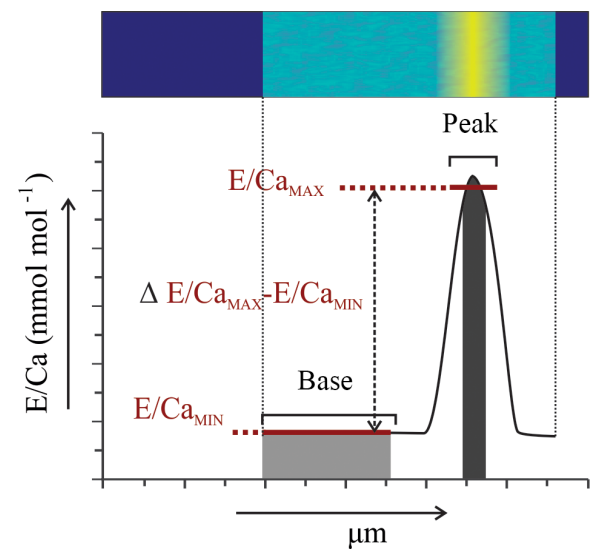

Figure 2. Illustration showing the theoretical transect map and resulting distribution profile with an area of selection for peak-base analysis.

\subsection{Intra-shell distribution of sulfur and magnesium}

All three species studied here, A. tepida, B. marginata and A. lessonii, show alternating bands with high and low concentrations of $\mathrm{Mg}$ and $\mathrm{S}$, but the absolute values of these minimum and maximum values differ between species (Fig. 5). For all three species we observe a positive correlation between $\mathrm{Mg} / \mathrm{Ca}$ EPMA and $\mathrm{S} / \mathrm{Ca}$ EPMA profiles of different transects (example in Fig. 1c). For all transect maps, the av- erage $\mathrm{S} / \mathrm{Ca}$ EPMA and $\mathrm{Mg} / \mathrm{Ca}$ EPMA is calculated and average $\mathrm{S} / \mathrm{Ca} \mathrm{a}_{\mathrm{EPMA}}$ and $\mathrm{Mg} / \mathrm{Ca} \mathrm{a}_{\mathrm{EPMA}}$ are, respectively, $1.7 \pm 0.1$ and $3.9 \pm 0.2 \mathrm{mmol} \mathrm{mol}^{-1}$ for A. tepida, $1.8 \pm 0.2$ and $5.5 \pm$ $0.4 \mathrm{mmol} \mathrm{mol}^{-1}$ for B. marginata and $2.4 \pm 0.3$ and $23.9 \pm$ $2.3 \mathrm{mmol} \mathrm{mol}^{-1}$ for $A$. lessonii. The values for $\mathrm{S} / \mathrm{Ca}_{\mathrm{EPMA}}$ versus $\mathrm{Mg} / \mathrm{Ca}$ EPMA of each transect map are plotted in Fig. 6, and this figure includes all transects studied, which is between one and three transects per chamber (for locations see Figs. S1-S3).

For all three studied species, values of average $\mathrm{S} / \mathrm{Ca}$ EPMA and $\mathrm{Mg} / \mathrm{Ca}$ EPMA of individual transects are significantly positively related for the three species, assuming a linear regression. The relationship can be described as $\mathrm{S} / \mathrm{Ca}$ EPMA $=$ $0.38 \cdot \mathrm{Mg} / \mathrm{Ca} \mathrm{EPMA}_{\mathrm{EPM}}+0.28$ for Ammonia tepida $\left(R^{2}=0.47\right.$; $p<0.0005), \mathrm{S} /$ CaEPMA $=0.43 \cdot \mathrm{Mg} / \mathrm{Ca}$ EPMA -0.18 for $B u$ limina marginata $\left(R^{2}=0.82 ; p<0.0005\right)$ and $\mathrm{S} / \mathrm{Ca} \mathrm{EPMA}=$ $0.089 \cdot \mathrm{Mg} / \mathrm{Ca} \mathrm{EPMA}+0.26$ for Amphistegina lessonii $\left(R^{2}=\right.$ $0.42 ; p<0.0025)$. Based on the slopes of the regressions, $\mathrm{S} / \mathrm{Ca}_{\mathrm{EPMA}}$ increases, with $\sim 38 \%-43 \%$ for A. tepida and B. marginata, respectively, and $\sim 9 \%$ for $A$. lessonii relative to $\mathrm{Mg} / \mathrm{Ca} a_{\text {EPMA }}$, from now on referred to as " $\mathrm{S} / \mathrm{Ca}-\mathrm{Mg} / \mathrm{Ca}$ slope". Amphistegina lessonii has the highest $\mathrm{S}$ incorporation but the least sensitive $\mathrm{S} / \mathrm{Ca}-\mathrm{Mg} / \mathrm{Ca}$ slope (Fig. 6).

\subsection{Peak-base analysis}

Based on 12 peak analyses, A. tepida has both the lowest peak and base values ( $E /$ CaPEAK $\left./ E / \mathrm{Ca}_{\mathrm{BASE}}\right)$ with $4.9 / 3.5$ 

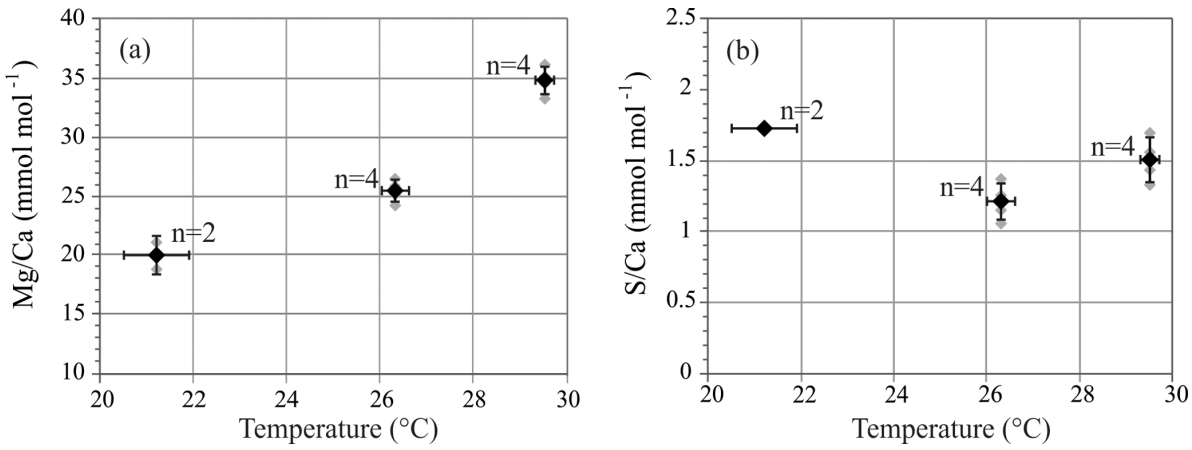

Figure 3. $\mathrm{Mg} / \mathrm{Ca}$ (a) and $\mathrm{S} / \mathrm{Ca}(\mathbf{b})$ of $A$. lessonii from the controlled temperature experiment. Sector field ICP-MS measurements (grey symbols) and average values $\pm \mathrm{SD}$ (black symbols) of grouped specimens. Horizontal error bars represent \pm SD of temperature conditions. $n$ is number of groups measured.

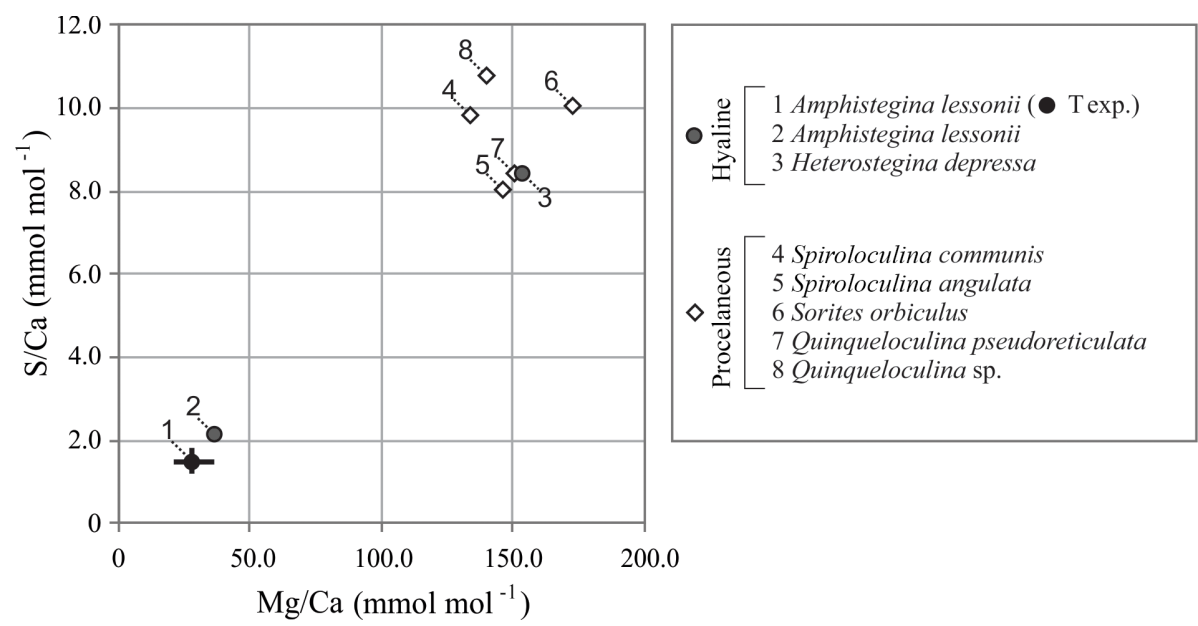

Figure 4. Compilation of $\mathrm{S} / \mathrm{Ca}$ versus $\mathrm{Mg} / \mathrm{Ca}$ of foraminifera from the aquarium in Burgers' Zoo (circles are hyaline species; diamonds are porcelaneous species). Average values of the foraminifera from the temperature-controlled experiment are given in black, with maximum and minimum ranges. Numbers indicate species.

and $2.1 / 1.5 \mathrm{mmol} \mathrm{mol}^{-1}$ for $\mathrm{Mg} / \mathrm{Ca}$ EPMA and S/CaEPMA, respectively. For $B$. marginata we analyzed eight transects, with average peak and base values of 7.0/4.1 and 2.5/1.5 for Mg/CaEPMA and S/CaEPMA, respectively. Based on nine transects, A. lessonii has the highest values for mmol mol ${ }^{-1}$ both $\mathrm{S} / \mathrm{Ca}_{\mathrm{EPMA}}$ and $\mathrm{Mg} / \mathrm{Ca}_{\mathrm{EPMA}}$ for peak and base, $56.6 / 20.2$ and $6.9 / 1.9 \mathrm{mmol} \mathrm{mol}^{-1}$ for $\mathrm{Mg} / \mathrm{CaEPMA}$ and S/CaEPMA, respectively. These data are summarized in Fig. 7 and Table 2.

Peak factors of $\mathrm{Mg} / \mathrm{Ca} a_{\text {EPMA }}$ and S/CaEPMA are very similar within the species $A$. tepida and B. marginata, respectively, between $1.4 \times(\mathrm{Mg} / \mathrm{Ca}$ EPMA $)$ and $1.5 \times(\mathrm{S} / \mathrm{Ca})$ for A. tepida and $1.7 \times$ (both $\mathrm{Mg} / \mathrm{Ca}$ EPMA and S/CaEPMA) for $B$. marginata. For A. lessonii the peak factor is much higher for both S/CaEPMA $(3.6 \times)$ and $\mathrm{Mg} / \mathrm{Ca}$ EPMA $(2.8 \times)$, indicating more pronounced peaks in the latter species. The peak and base value of S/CaEPMA are very similar for both low $\mathrm{Mg}$ species; average base values are $1.5 \mathrm{mmol} \mathrm{mol}^{-1}$ and peak values are $2.1-2.5 \mathrm{mmol} \mathrm{mol}^{-1}$.
Amphistegina lessonii has slightly higher base values for $\mathrm{S} /$ CaEPMA $\left(1.9 \mathrm{mmol} \mathrm{mol}^{-1}\right)$, but the average peak value of $\mathrm{S} / \mathrm{Ca}_{\text {EPMA }}$ is higher $\left(6.9 \mathrm{mmol} \mathrm{mol}^{-1}\right)$. When comparing the difference between peak values of $\mathrm{Mg} / \mathrm{Ca}$ and $\mathrm{S} / \mathrm{Ca}$, the $\mathrm{S} / \mathrm{Ca}$ peak is $43 \%$ and $12 \%$ of the $\mathrm{Mg} / \mathrm{Ca}$ peak for both respective species $A$. tepida and $A$. lessonii, which might be reflected in the steeper slope of $\mathrm{S} / \mathrm{Ca}-\mathrm{Mg} / \mathrm{Ca}$ relation for $A$. tepida observed in the transects (Fig. 6).

\section{Discussion}

\subsection{Foraminiferal $\mathrm{S} / \mathrm{Ca}$ and $\mathrm{Mg} / \mathrm{Ca}$ as a function of temperature}

Shell $\mathrm{Mg} / \mathrm{Ca}$ of specimens of A. lessonii grown under controlled temperatures increases, with $1.8 \mathrm{mmol} \mathrm{mol}^{-1}$ per ${ }^{\circ} \mathrm{C}$ (Fig. 3). Even though the $\mathrm{Mg} / \mathrm{Ca}$-temperature relationship has been studied for Amphistegina lessonii in the field (Raja et al., 2005), to our knowledge, this is the first labora- 

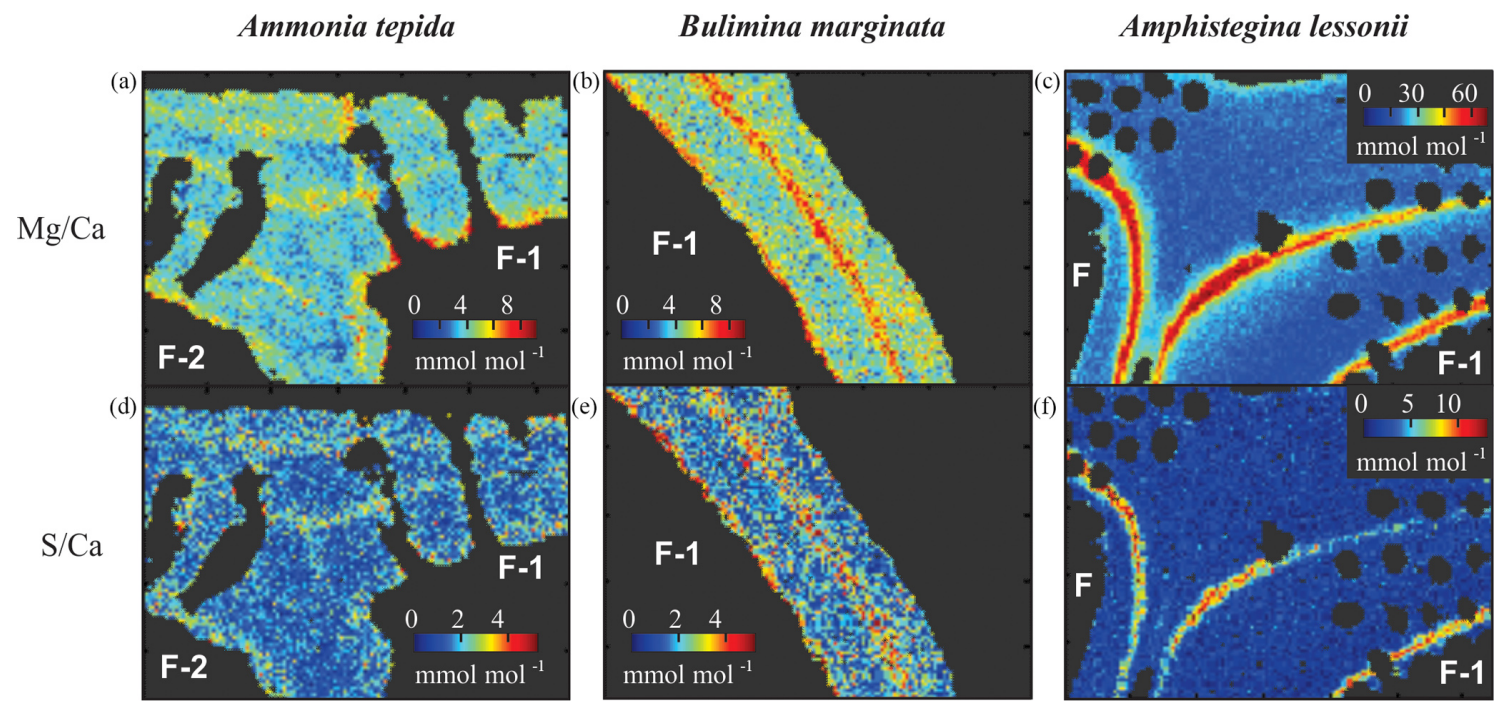

Figure 5. Typical distribution of $\mathrm{Mg} / \mathrm{Ca}(\mathbf{a}, \mathbf{b}, \mathbf{c})$ and $\mathrm{S} / \mathrm{Ca}(\mathbf{d}, \mathbf{e}, \mathbf{f})$ in three species of foraminifera, Ammonia tepida (a, d), Bulimina marginata $(\mathbf{b}, \mathbf{e})$ and Amphistegina lessonii $(\mathbf{c}, \mathbf{f})$. Chamber numbers are indicated in white on the interior part of the shell.
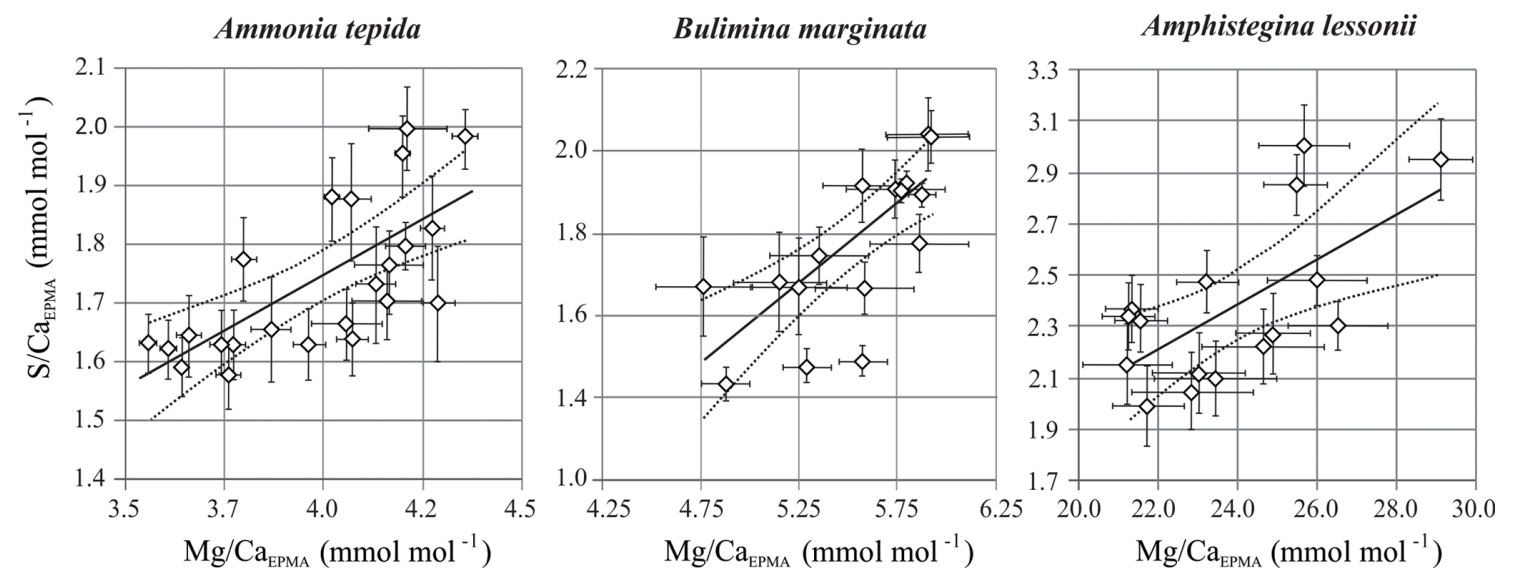

Figure 6. $\mathrm{S} / \mathrm{Ca}$ EPMA versus $\mathrm{Mg} / \mathrm{Ca}$ EPMA values $\pm \mathrm{SE}$ of the EPMA transect maps of different species. Every symbol represents the average $\mathrm{S} / \mathrm{Ca} \mathrm{EPMA}_{\mathrm{A}}$ and $\mathrm{Mg} / \mathrm{Ca} \mathrm{EPMA}_{\mathrm{A}}$ of a single transect map, which are positively correlated for Ammonia tepida $(n=24 ; \mathrm{S} / \mathrm{Ca} \mathrm{EPMA}=0.38$. $\mathrm{Mg} / \mathrm{Ca}$ EPMA +0.28 with $\left.R^{2}=0.47 ; p<0.0005\right)$, Bulimina marginata $\left(n=16 ; \mathrm{S} / \mathrm{Ca}\right.$ EPMA $=0.43 \cdot \mathrm{Mg} / \mathrm{Ca}$ EPMA -0.18 with $R^{2}=0.82$; $p<0.0005)$ and Amphistegina lessonii $\left(n=16 ; \mathrm{S} / \mathrm{Ca}\right.$ EPMA $=0.089 \cdot \mathrm{Mg} / \mathrm{Ca}$ EPMA +0.26 with $\left.R^{2}=0.42 ; p<0.0025\right)$. The location of the transects can be found in Table S1 and Figs. S1-S3. Note that the confidence interval (95\%) is indicated with dotted lines. Data are semiquantitative and therefore expressed as $E /$ CaEPMA, since calibration is performed against matrix unmatched mineral standards.

tory $\mathrm{Mg} / \mathrm{Ca}$-temperature calibration for Amphistegina spp. In inorganic carbonate precipitation studies, temperature is suggested to increase the thermodynamic Mg partitioning coefficient (Katz, 1973), which is also often used to explain the positive correlation between $\mathrm{Mg}$ and temperature in foraminiferal calcite. This abiogenic effect of temperature is, however, not a sufficient explanation and is therefore thought to be enhanced or modified by a biological processes (Branson et al., 2013). Studies on the distribution of $\mathrm{Mg}$ in foraminiferal calcite show that temperature modulates the $\mathrm{Mg} / \mathrm{Ca}$ values of both the high-concentration bands and the low-concentration baselines (Spero et al., 2015; Fehren- bacher et al., 2017; Geerken et al., 2019). Although we observe an increase in $\mathrm{S}$ with $\mathrm{Mg}$ for different species, $\mathrm{S}$ incorporation does not increase over the temperature range studied here (Fig. 3b). Within the species A. lessonii we found a $\mathrm{S} / \mathrm{Ca}-\mathrm{Mg} / \mathrm{Ca}$ slope of $9 \%$ (Fig. 6), which would translate to an increase in shell $\mathrm{S} / \mathrm{Ca}$ of $1.4 \mathrm{mmol} \mathrm{mol}^{-1}$, when $\mathrm{Mg} / \mathrm{Ca}$ values increase from 20 to $35 \mathrm{mmol} \mathrm{mol}^{-1}$ over the studied temperature range (Figs. 3 and S1). The absence of an effect of temperature on $\mathrm{S} / \mathrm{Ca}$ suggests that the process responsible for increasing $\mathrm{Mg}$ does not affect $\mathrm{SO}_{4}^{2-}$ substitution for $\mathrm{CO}_{3}^{2-}$ in the crystal lattice. Since temperature-induced changes in $\mathrm{Mg}$ incorporation do not increase foraminiferal 
Table 2. Results from peak-base analysis of A. tepida $(n=11)$, B. marginata $(n=8)$ and A. lessonii $(n=10)$, with average peak $(E /$ Ca $\mathrm{MAX})$ and base $\left(E / \mathrm{Ca}_{\mathrm{MIN}}\right)$ values in mmol $\mathrm{mol}^{-1}$ and $\triangle \mathrm{MIN}-\mathrm{MAX}$ parameters $\left(\mathrm{mmol} \mathrm{mol}^{-1} ; E / \mathrm{Ca}_{\mathrm{MAX}}-E / \mathrm{Ca}_{\mathrm{MIN}}\right)$ and peak factor $(x$; $\left.E / \mathrm{Ca}_{\mathrm{MAX}} / \mathrm{E} / \mathrm{Ca}_{\mathrm{MIN}}\right)$; for details see methodology Sect. 2.3.4).

\begin{tabular}{|c|c|c|c|c|c|c|c|c|}
\hline \multirow[t]{3}{*}{ Species } & \multicolumn{4}{|c|}{$\mathrm{Mg} / \mathrm{Ca}_{\mathrm{EPMA}}\left(\mathrm{mmol} \mathrm{mol}^{-1}\right)$} & \multicolumn{4}{|c|}{$\mathrm{S} / \mathrm{Ca}_{\mathrm{EPMA}}\left(\mathrm{mmol} \mathrm{mol}^{-1}\right)$} \\
\hline & \multirow[t]{2}{*}{ Peak } & \multirow[t]{2}{*}{ Base } & \multicolumn{2}{|c|}{$\Delta E / \mathrm{Ca}_{\mathrm{MAX}}-E / \mathrm{Ca}_{\mathrm{MIN}}$} & \multirow[t]{2}{*}{ Peak } & \multirow[t]{2}{*}{ Base } & \multicolumn{2}{|c|}{$\Delta E / \mathrm{Ca}_{\mathrm{MAX}}-E / \mathrm{Ca}_{\mathrm{MIN}}$} \\
\hline & & & $\mathrm{mmol} \mathrm{mol}^{-1}$ & $x$ & & & $\mathrm{mmol} \mathrm{mol}^{-1}$ & $x$ \\
\hline A. tepida $(n=11)$ & $4.9 \pm 0.7$ & $3.5 \pm 0.2$ & 1.5 & 1.4 & $2.1 \pm 0.4$ & $1.5 \pm 0.1$ & 0.7 & 1.5 \\
\hline B. marginata $(n=8)$ & $7.0 \pm 1.4$ & $4.1 \pm 0.9$ & 2.9 & 1.7 & $2.5 \pm 0.9$ & $1.5 \pm 0.1$ & 1.0 & 1.7 \\
\hline A. lessonii $(n=10)$ & $56.6 \pm 10.2$ & $20.2 \pm 4.3$ & 36.4 & 2.8 & $6.9 \pm 1.4$ & $1.9 \pm 0.2$ & 5.0 & 3.6 \\
\hline
\end{tabular}

$\mathrm{S} / \mathrm{Ca}, \mathrm{Mg} / \mathrm{Ca}$ and $\mathrm{S} / \mathrm{Ca}$ might therefore covary due to a different process, possibly by mechanisms involved in biomineralization.

\subsection{Mg and S distribution in the foraminiferal shell}

For all three species studied here we observe a positive correlation between $\mathrm{Mg} / \mathrm{Ca}$ and $\mathrm{S} / \mathrm{Ca}$ within chamber walls (intra-specimen variability; for an example, see Fig. 1c and last part of Sect. 3.3), between transect maps for each species (inter-specimen variability; Fig. 6) and between species (inter-species variability; Fig. 4). Both bands of high S (and high $\mathrm{Mg}$ ) seem to be located close to organic linings, as shown previously for A. gibbosa (by EPMA; van Dijk et al., 2017a), A. lobifera (by electron probe WDS; Erez, 2003) and Orbulina universa (by nanoSIMS; Paris et al., 2014). The presence of organic material could cause a higher Mg content due to increased adsorption of $\mathrm{Mg}$ (Mavromatis et al., 2017). If this is also the case for other elements, including $S$, this could explain the observed covariation within chambers (Fig. 5), as suggested earlier for the planktonic foraminifer Pulleniatina obliquiloculata by Kunioka et al. (2006). However, this is disputed by the work of Busenberg and Plummer (1985) and Kitano et al. (1975), which shows that $\mathrm{SO}_{4}^{2-}$ (as well as Na, Amiel et al., 1973) is predominately present in solid solution and not as a component of the organic matrix of biogenic $(\mathrm{Mg})$ calcites.

As shown in Fig. 1d, the relative intensity of $\mathrm{Mg} / \mathrm{Ca}$ and $\mathrm{S} / \mathrm{Ca}$ for different peaks in the same transect are not always similar (e.g., rightmost peaks in $\mathrm{Mg} / \mathrm{Ca}$ and $\mathrm{S} / \mathrm{Ca}$ are equally high, whereas the $\mathrm{S} / \mathrm{Ca}$ peak in the middle of the chamber wall is much lower than that of $\mathrm{Mg} / \mathrm{Ca}$ ), suggesting that $\mathrm{S}$ and $\mathrm{Mg}$ are spatially (and potentially temporary) correlated, but their concentrations must be partly decoupled as well. For $\mathrm{Mg} / \mathrm{Ca}$, peak and base values are higher for A. lessonii than for the low Mg species A. tepida and B. marginata (Fig. 7). The higher $\mathrm{Mg} / \mathrm{Ca}$ in shells of $A$. lessonii compared to the two low $\mathrm{Mg}$ species (A. tepida and B. marginata) appears to be caused by an increase in both peak and base concentrations in A. lessonii specimens, already suggested by Geerken et al. (2019). In contrast, the base values (i.e., non-band area) of $\mathrm{S} / \mathrm{Ca}$ seem to be very similar for all the three species
(1.5 $\pm 0.1 \mathrm{mmol} \mathrm{mol}^{-1}$ for both A. tepida and B. marginata and $1.9 \pm 0.2 \mathrm{mmol} \mathrm{mol}^{-1}$ for $A$. lessonii) suggesting that the increase in $\mathrm{S} / \mathrm{Ca}$ for species with higher $\mathrm{Mg}$ incorporation (Fig. 4) might be due to higher $\mathrm{S}$ peaks in the $\mathrm{S} / \mathrm{Ca}$ banding.

By comparing $\mathrm{S} / \mathrm{Ca}$ and $\mathrm{Mg} / \mathrm{Ca}$ values within transects we can test whether there is a correlation of $\mathrm{S} / \mathrm{Ca}$ and $\mathrm{Mg} / \mathrm{Ca}$ between specimens of the same species (inter-specimen variability). Individual transects were compared for each of the three species, showing a significant positive correlation between S/CaEPMA and Mg/CaEPMA (Fig. 6). Based on the slopes of the regression, $\mathrm{S} / \mathrm{Ca}$ increases with $\sim 37 \%$ and $\sim 39 \%$ for A. tepida and B. marginata, respectively, and $\sim 9 \%$ for A. lessonii relative to $\mathrm{Mg} / \mathrm{Ca}$. The larger benthic foraminifer $A$. lessonii has the highest $\mathrm{S}$ incorporation but the least sensitive $\mathrm{S} / \mathrm{Ca}-\mathrm{Mg} / \mathrm{Ca}$ slope. In all species, higher or lower average $\mathrm{Mg} / \mathrm{Ca}$ and $\mathrm{S} / \mathrm{Ca}$ values are likely caused by, respectively, more or less intense banding between specimens (i.e., inter-species variability). The peak of bands of $\mathrm{Mg}$ and $\mathrm{S}$ of the small benthic species (A. tepida and $B$. marginata) are much closer. Peak $\mathrm{S} / \mathrm{Ca}$ are $43 \%$ and $36 \%$ of $\mathrm{Mg} / \mathrm{Ca}$, respectively, in these species, rather than for $A$. lessonii in which the $\mathrm{S} / \mathrm{Ca}$ peak is $12 \%$ of the $\mathrm{Mg} / \mathrm{Ca}$ peak. This results in a higher relative increase in $\mathrm{S} / \mathrm{Ca}$ with $\mathrm{Mg} / \mathrm{Ca}$ for the small benthic species and thus a steeper $\mathrm{S} / \mathrm{Ca}-\mathrm{Mg} / \mathrm{Ca}$ slope. Still, although the slopes differ between these groups, $\mathrm{S} / \mathrm{Ca}$ and $\mathrm{Mg} / \mathrm{Ca}$ are consistently positively correlated.

\subsection{What controls $\mathrm{Mg}^{2+}$ and $\mathrm{SO}_{4}^{2-}$ uptake?}

Correlation between $\mathrm{S} / \mathrm{Ca}$ and $\mathrm{Mg} / \mathrm{Ca}$ in foraminiferal calcite (Fig. 6) might reflect (i) precipitation processes occurring at the crystal-solution interface (e.g., effects of lattice strain and crystal growth rate) or in the solution occupying the site of calcification (e.g., speciation of elements in seawater and the effect of elevated $\mathrm{pH}$ ), (ii) biomineralizationrelated processes, like a coupling of ion transport to the site of calcification, or (iii) a combination of both. The amount of variability and unknowns in combination with the lack of knowledge of crucial processes involved in foraminiferal calcification make it challenging to assess which processes are ultimately responsible for the uptake and incorporation of both sulfate and magnesium into foraminiferal calcite. How- 

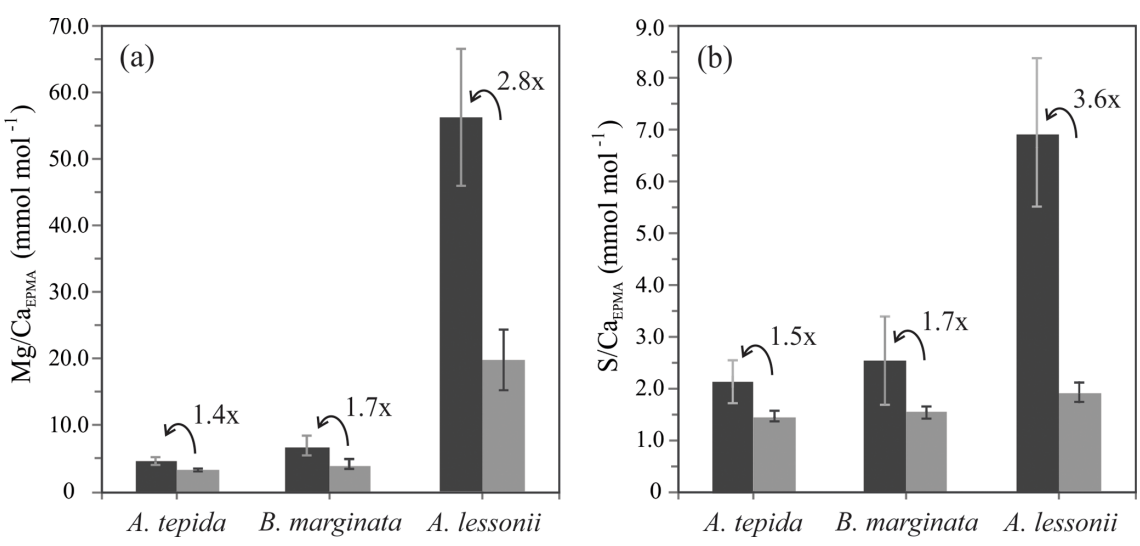

Figure 7. Average peak (black bars) and base (grey bars) values (Mg/CaEPMA, panel a; S/CaEPMA, panel b) with "peak factor" $\left(E / \mathrm{Ca}_{\mathrm{MAX}} / E / \mathrm{Ca}_{\mathrm{MIN}}\right.$; see methodology Sect. 2.3.4 and Fig. 2) of three investigated species, low Mg species $-A$. tepida and B. marginata - and intermediate Mg species - A. lessonii. Error bars indicate 2 SD. For details, see Table 2.

ever, the observed lack of a temperature effect on $\mathrm{S}$ incorporation, in contrast to the major impact of temperature on $\mathrm{Mg} / \mathrm{Ca}$, may render some explanations more likely than others.

\subsubsection{Calcite precipitation and physicochemical conditions}

The observed link between $\mathrm{S} / \mathrm{Ca}$ and $\mathrm{Mg} / \mathrm{Ca}$ might be explained by investigating parameters involved in inorganic precipitation studies. Chemical processes operating at the crystal-solution interface or in the fluid contained in the site of calcification might give insights into the observed correlation between sulfate and magnesium incorporation in foraminiferal calcite, as well as the temperature effect on $\mathrm{Mg}$ incorporation. Magnesium ions in the parent solution have been found to increase the coprecipitation of other elements (Okumura and Kitano, 1986). However, this is observed for alkali metal ions, which are in interstitial positions or substitute for $\mathrm{Ca}^{2+}$ in the crystal lattice, while $\mathrm{SO}_{4}^{2-}$ is hypothesized to exchange for $\mathrm{CO}_{3}^{2-}$ ions (Pingitore et al., 1995; Perrin et al., 2017; Berry, 1998). Besides promoting coprecipitation, incorporation of magnesium in carbonate is suggested to cause strain on the crystal lattice, leading to distortion and an increase in the incorporation of other elements (Mucci and Morse, 1983). This theory has been used to explain incorporation of certain elements, like $\mathrm{Na}^{+}$and $\mathrm{Sr}^{2+}$ in larger benthic foraminifera (Evans et al., 2015). Besides the lack of study on the incorporation of sulfate with increasing Mg content, based on our data, the correlation between $\mathrm{Mg} / \mathrm{Ca}$ and $\mathrm{S} / \mathrm{Ca}$ cannot be explained by crystal lattice distortion. The lack of response of $\mathrm{S} / \mathrm{Ca}$ to (temperature-induced) changes in $\mathrm{Mg} / \mathrm{Ca}$ (Fig. 3) together with the similar base values of $\mathrm{S} / \mathrm{Ca}$ for all three investigated species, while base values for $\mathrm{Mg} / \mathrm{Ca}$ vary between species (Fig. 7), shows that $\mathrm{S} / \mathrm{Ca}$ and $\mathrm{Mg} / \mathrm{Ca}$ are not always correlated, which should be the case with this hypothesis.
The effect of temperature on $\mathrm{Mg} / \mathrm{Ca}$ has been comprehensively studied for inorganic carbonates, by controlled precipitation experiments (for a summary see Mucci, 1987). Over the last decades, several explanations have been proposed to explain the relation between temperature and $\mathrm{Mg}$ incorporation in inorganic carbonates. Firstly, the partitioning of certain elements in inorganic experiments heavily relies on precipitation rate (e.g., Lorens, 1981). This was suggested for $\mathrm{Mg}$ incorporation (Chilingar, 1962), which may indicate that the increase in foraminiferal $\mathrm{Mg} / \mathrm{Ca}$ in our study could be explained by a positive effect of temperature on precipitation rate. However, this was disputed by several studies (e.g., Mucci and Morse, 1983; Mucci et al., 1985), showing inorganic precipitation rate does not change with temperature but depends on the $\mathrm{Mg} / \mathrm{Ca}$ ratio of the parent solution. On the other hand, partitioning of $\mathrm{SO}_{4}^{2-}$ in synthetic calcite does increase with precipitation rate (Busenberg and Plummer, 1985). However, partitioning of elements in inorganic precipitation studies might differ greatly from foraminiferal calcite, since shell precipitation rate could be decoupled from crystal precipitation rate. To discuss if $\mathrm{S} / \mathrm{Ca}$, as well as $\mathrm{Mg} / \mathrm{Ca}$ of foraminiferal calcite is affected by the growth rate of foraminiferal shells, we would need to study the precipitation rate of foraminiferal calcite as a function of temperature.

It has been proposed that calcium and magnesium transport to the site of calcification requires complete or partial dehydration of these ions, an energy-consuming process that is influenced by temperature (Mucci, 1986; Morse et al., 2007; Arvidson and Mackenzie, 2000). Rehydration of these ions at the site of calcification (SOC) may furthermore determine isotopic fractionation during calcium carbonate precipitation (Mavromatis et al., 2013). Since dehydration of magnesium ions costs less energy at higher temperatures, it may be expected that there would be more dehydrated and transportable $\mathrm{Mg}$ available. This would lead to an increased (accidental) transport of $\mathrm{Mg}^{2+}$ to the SOC by $\mathrm{Ca}^{2+}$ pumps, 
leading to a positive effect of temperature on $\mathrm{Mg} / \mathrm{Ca}$ or an increased selective removal of $\mathrm{Mg}^{2+}$ resulting in theory in a lower shell $\mathrm{Mg} / \mathrm{Ca}$ at higher temperatures. Since the latter is not observed, the effect of the (de)hydration of $\mathrm{Mg}$ ions is only likely in biomineralization models where $\mathrm{Mg}$ is not selectively removed, like the transmembrane transport (TMT) mixing model (Nehrke et al., 2013). Although this explains the lack of a clear temperature effect on $\mathrm{S} / \mathrm{Ca}$ values, it does not explain the co-regulation of $\mathrm{S} / \mathrm{Ca}$ and $\mathrm{Mg} / \mathrm{Ca}$.

Speciation of elements in seawater as a function of carbonate chemistry parameters (e.g., $\left[\mathrm{CO}_{3}^{2-}\right]$ and/or $\mathrm{pH}$ ) has been proposed as an explanation for the incorporation of $\mathrm{Zn}$ and $\mathrm{U}$ in foraminiferal calcite (Djogić and Branica, 1991; Keul et al., 2013; van Dijk et al., 2017c). The effect of temperature and $\mathrm{pH}$ on the activity or bioavailability of different chemical species of $\mathrm{Mg}$ and $\mathrm{S}$ in seawater has not been studied so far but can be modeled using the software package PHREEQC (Parkhurst and Appelo, 1999) using the insoftware llnl database and standard seawater composition. This allows us to test two different conditions: (A) variable temperature with stable $p \mathrm{CO}_{2}$ (current atmosphere) and salinity (35) and (B) constant temperature and salinity $\left(25^{\circ} \mathrm{C}\right.$ and 35, respectively) and increasing $\mathrm{pH}$ and stable alkalinity of $2300 \mu \mathrm{mol} \mathrm{kg}^{-1}$ seawater (Fig. 8). Using CO2SYS, other carbon parameters, including dissolved inorganic carbon (DIC), were calculated with $\mathrm{K} 1$ and $\mathrm{K} 2$ from of Lueker et al. (2000).

At variable temperature, the model shows a small decrease in the activity of $\mathrm{SO}_{4}^{2-}$, whereas for $\mathrm{Mg}$ species, only activity of $\mathrm{MgCO}_{3}$ complexes increases, while activity ratio of $\mathrm{Mg}^{2+}$ and $\mathrm{Ca}^{2+}$ remains stable over this range. If foraminifera use $\mathrm{MgCO}_{3}$ complexes when calcifying, this could explain the observed temperature effect. When temperature changes from 20 to $30^{\circ} \mathrm{C}$, the activity of $\mathrm{SO}_{4}^{2-}$ decreases by $8 \%$ (due to a small increase in the activity of $\mathrm{MgSO}_{4}^{-}$), while the activity of $\mathrm{MgCO}_{3}$ increases by $28 \%$. This could, in part, explain the lack and presence of an effect of temperature on foraminiferal $\mathrm{S} / \mathrm{Ca}$ and $\mathrm{Mg} / \mathrm{Ca}$, respectively, when assuming foraminifera incorporate this species of magnesium during biomineralization.

This might, in part, control the ultimate $E / \mathrm{Ca}$ if these species are used to precipitate the foraminiferal shell. During chamber addition, $\mathrm{pH}$ changes externally to the foraminifera (pH $<8$; Glas et al., 2012; Toyofuku et al., 2017) and internally at the site of calcification or in seawater vacuoles (de Nooijer et al., 2009). Availability of $\mathrm{SO}_{4}^{2-}$ remains similar when $\mathrm{pH}$ changes, while presence of $\mathrm{MgCO}_{3}$ increases with $\mathrm{pH}$, especially when $\mathrm{pH}>8$ (Fig. 8b), which argues in favor of a role of $\mathrm{MgCO}_{3}$ complexes in foraminiferal calcification. Still, when comparing the amplitude in $\mathrm{Mg} / \mathrm{Ca}$ from 21.2 to $29.5^{\circ} \mathrm{C}$, incorporation almost doubles $(\mathrm{Mg} / \mathrm{Ca}$ increases $\sim 72 \%$; Fig. 3 and Table S2), whereas the change in relative abundance of $\mathrm{MgCO}_{3}$ complexes increases only by $28 \%$. Hence, changes in the amount of $\mathrm{MgCO}_{3}$ complexes does not explain the full range observed.

\subsubsection{Element transport during biomineralization}

Based on the transmembrane transport mixing model (TMT; Nehrke et al., 2013; Mewes et al., 2015), $\mathrm{Mg}^{2+}$ might be accidentally transported to the site of calcification by Ca channels or pumps, as well as by passive transport (e.g., leakage, initial seawater enclosed at the site of calcification or seawater endocytosis), while $\mathrm{SO}_{4}^{2-}$ would not be transported by the $\mathrm{Ca}$ channels or pumps. Only prior to or at the first stages of chamber formation, when the membrane is perhaps not fully closed (Nagai et al., 2018) and the fluid in the site of calcification (SOC) resembles seawater, $\mathrm{SO}_{4}^{2-}$ is incorporated due to the relatively high $\left[\mathrm{SO}_{4}^{2-}\right]$ in seawater. The clear single peak at the start of the lamella, as shown by the EPMA analysis, might indicate there is either much more sulfate present at the start of calcification, or the $\mathrm{CO}_{3}^{2-}$ concentration is still low, and hence the $\mathrm{SO}_{4}^{2-}$ to $\mathrm{CO}_{3}^{2-}$ ratio.

In the seawater vacuolization (SWV) model (Bentov et al., 2009), the main source of ions is from the endocytosis of seawater. The $\mathrm{Mg} / \mathrm{Ca}$ of the fluid in these seawater vacuoles is lowered $\left(<0.1 \mathrm{~mol} \mathrm{~mol}^{-1}\right.$; Evans et al., 2018), but it is not known if the sulfate concentration is regulated in these vacuoles, making it impossible to assess whether $\mathrm{Mg}^{2+}$ and $\mathrm{SO}_{4}^{2-}$ concentrations in the vacuoles are correlated. However, the (small) increase in $\mathrm{pH}$ of the vacuoles $(\sim 8.7$ for species Amphistegina lobifera; Bentov et al., 2009) can decrease the $\left[\mathrm{SO}_{4}^{2-}\right] /\left[\mathrm{CO}_{3}^{2-}\right]$ of the vacuoles.

The similar and spatial stable baseline values for $\mathrm{S} / \mathrm{Ca}$ for the three species studied here suggest that uptake or transport of $\mathrm{SO}_{4}^{2-}$ to the site of calcification during the shell thickening phase of calcification is matched by incorporation of $\mathrm{SO}_{4}^{2-}$ into the shell matrix, leading to a similar $\mathrm{S} / \mathrm{Ca}$ of the nonband areas. Considering both models individually, it is impossible to explain the correlation between $\mathrm{SO}_{4}^{2-}$ and $\mathrm{Mg}^{2+}$ incorporation. However, by considering certain constraints on element transport offered by both models, we can hypothesize which $E / \mathrm{Ca}$ might be characteristic for both endmember models to understand the relation of $\mathrm{Mg} / \mathrm{Ca}$ and $\mathrm{S} / \mathrm{Ca}$ on species scale (Fig. 4). We consider three different processes, each resulting in a different $E / \mathrm{Ca}$ signature that foraminifera might employ to take up calcium and carbon.

i. $S W V$ dominated. During endocytosis, $\mathrm{Mg} / \mathrm{Ca}$ in the vacuoles will be actively lowered, while $\left[\mathrm{SO}_{4}^{2-}\right] /\left[\mathrm{CO}_{3}^{2-}\right]$ in the vacuoles is lowered due to increase in $\mathrm{pH}$ in the vacuoles.

ii. Ca channel-dominated. Due to the transport of $\mathrm{Ca}^{2+}$ through $\mathrm{Ca}$ channels to the site of calcification, $\mathrm{Mg} / \mathrm{Ca}$ will be lowered, while there is no effect on the $\mathrm{SO}_{4} / \mathrm{CO}_{3}$ from which calcite is precipitated.

iii. Proton pumping. Pumping of protons out of the SOC (Toyofuku et al., 2017) will increase its $\mathrm{pH}$ and shift the speciation of inorganic carbon towards $\mathrm{CO}_{3}^{2-}$. This in- 

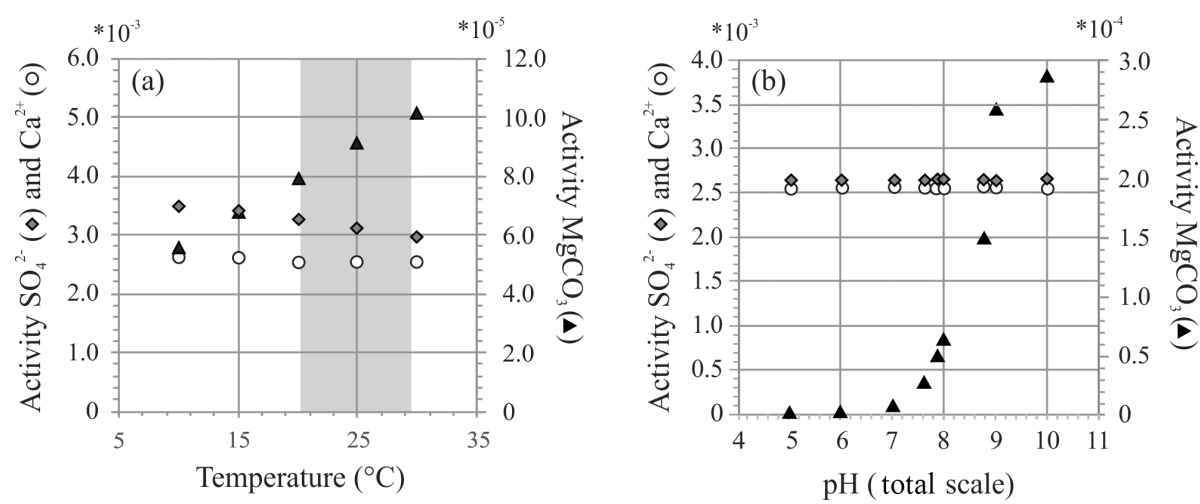

Figure 8. Two exercises using PHREEQC showing activity of $\mathrm{SO}_{4}^{2-}, \mathrm{Ca}^{2+}$ and $\mathrm{MgCO}_{3}$ at (a) different temperatures (temperature range of controlled culture experiment indicated in grey) and (b) different $\mathrm{pH}$. Chosen $\mathrm{pH}$ range reflects external and internal $\mathrm{pH}$ shift during chamber formation (Glas et al., 2012; de Nooijer et al., 2009; Toyofuku et al., 2017).

crease in $\left[\mathrm{CO}_{3}^{2-}\right]$ will lead to lower $\mathrm{SO}_{4}^{2-} / \mathrm{CO}_{3}^{2-}$ values in the site of calcification.

All currently available data from previous culture and field studies in which values for both $\mathrm{S} / \mathrm{Ca}$ and $\mathrm{Mg} / \mathrm{Ca}$ data are available (van Dijk et al., 2017a; Mezger et al., 2019), combined with values from the controlled temperature study and the Burgers' Zoo specimens, as well as the semiquantitative data from EPMA analysis (Sect. 3.3), are presented in Fig. 9 and Table S4. Because carbonate-associated sulfur in foraminifera is incorporated as $\mathrm{SO}_{4}^{2-}$ and the ratio between $\mathrm{Ca}$ and $\mathrm{CO}_{3}$ is $\sim 1, \mathrm{~S} / \mathrm{Ca}$ can be converted $(1: 1)$ and expressed as $\mathrm{SO}_{4}^{2-} / \mathrm{CO}_{3}^{2-}$.

In general, $\mathrm{S}$ incorporation increases linearly with increasing $\mathrm{Mg}$ content, with a $\mathrm{S} / \mathrm{Ca}-\mathrm{Mg} / \mathrm{Ca}$ slope of $\sim 6 \%$, i.e., if $\mathrm{Mg} / \mathrm{Ca}$ increases by $1 \mathrm{mmol} \mathrm{mol}^{-1}, \mathrm{~S} / \mathrm{Ca}$ increases by $0.06 \mathrm{mmol} \mathrm{mol}^{-1}$. Interestingly, no offset is observed between porcelaneous and high Mg hyaline species, as has been noted before for other elements (as observed for, e.g., $\mathrm{Na} / \mathrm{Ca}$; van Dijk et al., 2017b). Both groups seem to have a characteristic chemical signature: hyaline species have in general low $\mathrm{S}$ and $\mathrm{Mg}$ incorporation (except for the high $\mathrm{Mg}$ hyaline species, like Heterostegina depressa), while porcelaneous species have high $\mathrm{S}$ and $\mathrm{Mg}$ values. The combination of low $\mathrm{S} / \mathrm{Ca}$ and $\mathrm{Mg} / \mathrm{Ca}$ for planktonic and small benthic hyaline foraminifera might be the result of the combination of $\mathrm{Ca}$ transport and proton pumping, two processes already linked in low $\mathrm{Mg}$ foraminifer Ammonia tepida (Toyofuku et al., 2017). High Mg hyaline and porcelaneous foraminifera seem to occupy the SWV dominated region, which is supported by both the observation of seawater vacuoles in hyaline species and the calcification pathway of porcelaneous species, which is suggested to take place intracellular in the form of calcite needle formation in vacuole-like structures. This data highlights the fundamentally different calcification pathways proposed before for these two groups (e.g., Berthold, 1976; Hemleben et al., 1986). However, due to the limited amount of constraints on both models it is cur- rently difficult to fully assess the impact of both calcification pathways on element incorporation, and therefore we cannot exclude other factors that might be responsible for the correlation between $\mathrm{Mg}$ and $\mathrm{S}$ incorporation. Furthermore, in Fig. 9 we also present $\mathrm{Mg} / \mathrm{Ca}$ values of inorganic calcite from Mucci and Morse (1983), values that are often used to compare $\mathrm{Mg} / \mathrm{Ca}$ values of foraminifera with inorganic calcite (Evans et al., 2015; van Dijk et al., 2017b). However, new evidence has arisen that foraminifera might precipitate vaterite, which ultimately transforms to calcite, indicating a complex pathway and partitioning of elements during calcification.

\subsubsection{Sulfate at the site of calcification}

Species-specific differences in the relative contribution of SWV and TMT might provide an explanation of our results. However, while this could give insights into the incorporation of $\mathrm{S}$ and $\mathrm{Mg}$ as a function of temperature and explain speciesspecific differences, we did not consider the inhibition effect of sulfate and the probable nonclassical calcification pathway foraminifera utilize to create their shell (Jacob et al., 2017). Sulfate is a known inhibitor for precipitation of calcite (e.g., Manoli and Dalas, 2000; Kitano, 1962) but does play a role in the transformation from amorphous calcium carbonate into vaterite (see Bots et al., 2012, and references therein). Vaterite transforms into calcite via dissolution-re-precipitation when solution $\mathrm{SO}_{4}^{2-}: \mathrm{CO}_{3}^{2-}<1.3$ (Fernández-Díaz et al., 2010). A recent study has proposed that certain species of planktonic foraminifera create their shell by a pathway involving vaterite phases that transform ultimately to calcite (Jacob et al., 2017), which might suggest the $\mathrm{SO}_{4}^{2-}: \mathrm{CO}_{3}^{2-}$ at the site of calcification is $>1$ when precipitation of the carbonate shell commences. Just prior to formation of a new chamber, the sulfate concentration at the SOC is probably similar to that in seawater, assuming the calcification fluid is composed of either a small volume of seawater enclosed by the protective envelope separating the SOC from seawater or 

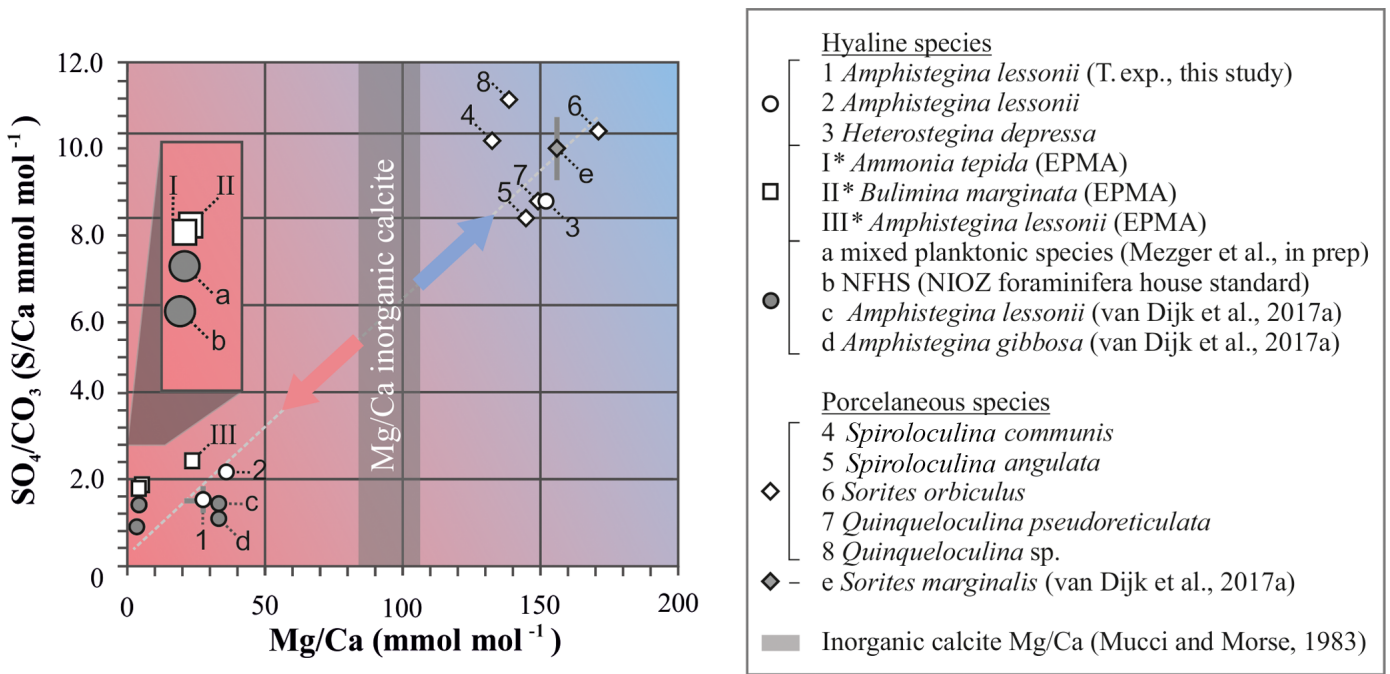

Figure 9. Average values of $\mathrm{S} / \mathrm{Ca}$, expressed as $\mathrm{SO}_{4}^{2-} / \mathrm{CO}_{3}^{2-}$, versus $\mathrm{Mg} / \mathrm{Ca}$ of different hyaline (circles) and porcelaneous (diamonds) species of foraminifera of this study (open symbols) and other studies (grey symbols), including values obtained for the NFHS (for a description see Mezger et al., 2016). Culture experiments with varying salinity (c), temperature (1) and $p \mathrm{CO}_{2}$ (d, e), min and maximum ranges are indicated by grey bars but in most cases fall within the symbol. Values of foraminiferal $E / C a$ can be found in Table S4. Values for $\mathrm{Mg} / \mathrm{Ca}$ of inorganic precipitated calcite of Mucci and Morse (1983) are indicated with the grey bars; SD is included. * Average values for transect maps (square symbols; for details see Sect. 3.3) are semiquantitative.

by seawater vacuoles ( $\mathrm{SWV}$ model). With a seawater concentration of $\sim 30 \mathrm{mM}\left[\mathrm{SO}_{4}^{2-}\right]$, it is very likely that the $\mathrm{SO}_{4}^{2-}$ : $\mathrm{CO}_{3}^{2-}$ at the site of calcification is $>1$, but it is dependent on the carbonate chemistry at the SOC. Laboratory experiments have revealed that the internal $\mathrm{pH}$ of a foraminifera is elevated, with (species-specific) values ranging from $\sim 8.75$ (Bentov et al., 2009) to $\geq 9$ (de Nooijer et al., 2009) at the start of shell formation due to proton pumping (Toyofuku et al., 2017), which lowers the $\mathrm{pH}$ in the microenvironment surrounding the foraminifer (Glas et al., 2012). When assuming the $\mathrm{SO}_{4}^{2-}$ and inorganic carbonate concentration at $\mathrm{SOC}$ is equal to natural seawater at $400 \mathrm{ppm} \mathrm{CO}_{2}\left(\sim 2650 \mathrm{mg} \mathrm{L}^{-2}\right.$ $\left.\left[\mathrm{SO}_{4}^{2-}\right], \sim 2100 \mu \mathrm{mol} \mathrm{L}{ }^{-1} \mathrm{DIC}\right)$, the elevation of internal $\mathrm{pH}$ to 9 creates a $\mathrm{SO}_{4}^{2-}: \mathrm{CO}_{3}^{2-}$ of $\sim 25$, leading to the stabilization of vaterite and a band enriched in $\mathrm{SO}_{4}^{2-}$ close to the primary organic sheet, which we observe in the chamber wall distribution of all three of our species (Fig. 5). Note that this is a maximum theoretical $\mathrm{SO}_{4}^{2-}: \mathrm{CO}_{3}^{2-}$, since $\mathrm{DIC}$ might be higher in the SOC, but it is very unlikely that the DIC increases to a point where the ratio will be $<1$. During precipitation, the $\mathrm{SO}_{4}^{2-}: \mathrm{CO}_{3}^{2-}$ likely decreases during the thickening of the chamber wall, due to continuous active pumping of protons out of the site of calcification (Toyofuku et al., 2017). This implies that the $\mathrm{S} / \mathrm{Ca}$ distribution in the foraminiferal chamber wall may reflect a change in $\mathrm{SO}_{4}^{2-} / \mathrm{CO}_{3}^{2-}$ of the calcifying fluid in the site of calcification (SOC) during precipitation of the shell wall. Assuming a stable $D$ during calcification (e.g., $D \times 1000=0.013$; Busenberg and Plummer, 1985), $\mathrm{SO}_{4}^{2-} / \mathrm{CO}_{3}^{2-}$ at the $\mathrm{SOC}$ would be a factor of 3.6 higher in the thin, high-concentration band (with an $\mathrm{S} / \mathrm{Ca}$ of $6.9 \mathrm{mmol} \mathrm{mol}^{-1}$; Fig. 7) compared to the broader, lowconcentration band (with an $\mathrm{S} / \mathrm{Ca}$ of $1.9 \mathrm{mmol} \mathrm{mol}^{-1}$ ). This decrease by a factor of 3.6 could be due to an increase in $\left[\mathrm{CO}_{3}^{2-}\right]$ and/or a decrease in $\left[\mathrm{SO}_{4}^{2-}\right]$ during precipitation. The latter could be the result of inclusion of small amounts of sulfate in the SOC at the beginning of chamber formation and ongoing incorporation of sulfate in the foraminiferal calcite. However, since the $\mathrm{S} / \mathrm{Ca}$ is not decreasing towards the outer side of the shell in the low-concentration band, the former process, i.e., increasing $\mathrm{CO}_{3}^{2-}$, might be more likely. An increase in $\mathrm{CO}_{3}^{2-}$ at the $\mathrm{SOC}$ from the first stage of chamber formation (high in $\mathrm{S} / \mathrm{Ca}$ ) to the broader second part (low in $\mathrm{S} / \mathrm{Ca}$ ) could be caused by an increase in internal $\mathrm{pH}$ due to proton pumping (Toyofuku et al., 2017). The band of high $\mathrm{S} / \mathrm{Ca}$ would then be precipitated when proton pumping has not yet reached its maximum rate and the internal $\mathrm{pH}$ is still rising (Glas et al., 2013). However, to confirm this hypothesis, a more precise characterization of the calcification fluid's chemistry is necessary.

\section{Conclusions}

Systematics in the incorporation of different elements in foraminiferal shells can be used to test calcification models and hence processes involved in precipitation of calcium carbonates. Our dataset, including both hyaline and porcelaneous species of foraminifera with a wide range of shell $\mathrm{Mg}$ content, shows a positive relation between $\mathrm{Mg}$ and $\mathrm{S}$ incorporated in their shells. This correlation can be found on 
species scale but also between specimens of the same species and on a microscale in the heterogeneous distribution in the shell wall. In contrast, we find no effect of temperature on the $\mathrm{S} / \mathrm{Ca}$ values of foraminiferal calcite, even though shell $\mathrm{Mg} / \mathrm{Ca}$ increases. The lack of an observed temperature effect on S/Ca for Amphistegina lessonii might be due to the decrease in activity of sulfate with temperature, counterbalancing the increase in $\mathrm{S} / \mathrm{Ca}$ due to increasing shell $\mathrm{Mg} / \mathrm{Ca}$. Nevertheless, the lack of certain crucial key factors, like the chemistry at the site of calcification, make it difficult to fully understand the pathway of both elements during calcification. The differences observed for the three species highlights the diversity of and variation in processes involved in biomineralization in foraminifera. Mechanisms suggested for inorganic precipitation, like, for example, crystal lattice strain, precipitation rate and ion dehydration, fail to independently explain our findings in full. Comparing our data with existing biomineralization models implies that, irrespective of the model, foraminiferal $\mathrm{Mg} / \mathrm{Ca}$ and $\mathrm{S} / \mathrm{Ca}$ are governed by two different but co-regulated pathways. $\mathrm{Mg} / \mathrm{Ca}$ is primarily affected by $\mathrm{Ca}$ (or $\mathrm{Mg}$ ) transport and passive transport, while $\mathrm{S} / \mathrm{Ca}$ is mainly governed by proton pump intensity and passive transport. The observed patterns imply that these pathways are spatially and temporally linked, and hence that for all species of foraminifera, take-up of calcium and carbon is co-regulated.

Data availability. Data are available and can be requested from the corresponding author (inge.van.dijk@nioz.nl).

Supplement. The supplement related to this article is available online at: https://doi.org/10.5194/bg-16-2115-2019-supplement.

Author contributions. IvD, LJdN and GJR planned and performed the temperature culture experiment. $\mathrm{CB}, \mathrm{AM}$ and $\mathrm{SO}$ obtained specimens used for EPMA. IvD, CB, AM and EG performed measurements and analyzed the results. GJR facilitated the technical realization of the study. All authors contributed to the discussion and interpretation of the results. The manuscript was written under the lead of IvD.

Competing interests. The authors declare that they have no conflict of interest.

Acknowledgements. We would like to thank Wim Boer for support with LA-Q-ICP-MS and SF-ICP-MS measurements and both Tilly Bouten and Sergei Matveev for technical support with the EPMA analysis. Lastly, we thank Jan-Berend Stuut for the usage of the Hitachi TM3000 SEM.
Financial support. This research has been supported by the Darwin Centre for Biogeosciences (project 3020), the Netherlands Earth System Science Center (grant no. 024.002.001), the University Bretagne Loire and Angers Loire Metropole (grant project MOXY), and the EC2CO-LEFE and CNRS (grant project MANGA 2D).

Review statement. This paper was edited by Hiroshi Kitazato and reviewed by Guillaume Paris and one anonymous referee.

\section{References}

Amiel, A. J., Friedman, G. M., and Miller, D. S.: Distribution and nature of incorporation of trace elements in modern aragonitic corals, Sedimentology, 20, 47-64, 1973.

Arvidson, R. S. and Mackenzie, F. T.: Temperature dependence of mineral precipitation rates along the $\mathrm{CaCO}_{3}-\mathrm{MgCO}_{3}$ join, Aquat. Geochem., 6, 249-256, 2000.

Barker, S., Greaves, M., and Elderfield, H.: A study of cleaning procedures used for foraminiferal $\mathrm{Mg} / \mathrm{Ca}$ paleothermometry, Geochem. Geophy., 4, https://doi.org/10.1029/2003GC000559, 2003.

Barras, C., Mouret, A., Nardelli, M. P., Metzger, E., Petersen, J., La, C., Filipsson, H. L., and Jorissen, F.: Experimental calibration of manganese incorporation in foraminiferal calcite, Geochim. Cosmochim. Ac., 237, 49-64, https://doi.org/10.1016/j.gca.2018.06.009, 2018.

Beerling, D. J. and Royer, D. L.: Convergent cenozoic $\mathrm{CO}_{2}$ history, Nat. Geosci., 4, 418-420, 2011.

Bentov, S. and Erez, J.: Impact of biomineralization processes on the $\mathrm{Mg}$ content of foraminiferal shells: A biological perspective, Geochem. Geophy., 7, Q01P08, https://doi.org/10.1029/2005GC001015, 2006.

Bentov, S., Brownlee, C., and Erez, J.: The role of seawater endocytosis in the biomineralization process in calcareous foraminifera, P. Natl. Acad. Sci. USA, 106, 21500-21504, https://doi.org/10.1073/pnas.0906636106, 2009.

Berry, J. N.: Sulfate in foraminiferal calcium carbonate: Investigating a potential proxy for sea water carbonate ion concentration, Master of Science, Massachusetts Institute of Technology, Cambridge, 88 pp., 1998.

Berthold, W.-U.: Biomineralisation bei milioliden Foraminiferen und die Matritzen-Hypothese, Naturwissenschaften, 63, 196197, 1976.

Bots, P., Benning, L. G., Rodriguez-blanco, J.-D., Roncal-Herrero, T., and Shaw, S.: Mechanistic insights into the crystallization of amorphous calcium carbonate to vaterite, Cryst. Growth Des., 12, 3806-3814, https://doi.org/10.1021/cg300676b, 2012.

Branson, O., Redfern, S. A., Tyliszczak, T., Sadekov, A., Langer, G., Kimoto, K., and Elderfield, H.: The coordination of $\mathrm{Mg}$ in foraminiferal calcite, Earth Planet. Sc. Lett., 383, 134-141, 2013.

Busenberg, E. and Plummer, L. N.: Kinetic and thermodynamic factors controlling the distribution of $\mathrm{SO}_{3}^{2-}$ and $\mathrm{Na}^{+}$in calcites and selected aragonites, Geochim. Cosmochim. Ac., 49, 713-725, 1985.

Chilingar, G. V.: Dependence on temperature of $\mathrm{Ca} / \mathrm{Mg}$ ratio of skeletal structures of organisms and direct chemical precipitates 
out of sea water, Bulletin of the Southern California Academy of Sciences, 61, 45-60, 1962.

de Nooijer, L. J., Toyofuku, T., and Kitazato, H.: Foraminifera promote calcification by elevating their intracellular pH, P. Natl. Acad. Sci. USA, 106, 15374-15378, https://doi.org/10.1073/pnas.0904306106, 2009.

de Villiers, S., Greaves, M., and Elderfield, H.: An intensity ratio calibration method for the accurate determination of $\mathrm{Mg} / \mathrm{Ca}$ and $\mathrm{Sr} / \mathrm{Ca}$ of marine carbonates by ICP-AES, Geochem. Geophy., 3, 2001GC000169, https://doi.org/10.1029/2001GC000169, 2002.

Djogić, R. and Branica, M.: Dissolved uranyl complexed species in artificial seawater, Mar. Chem., 36, 121-135, https://doi.org/10.1016/S0304-4203(09)90058-5, 1991.

Dueñas-Bohórquez, A., Raitzsch, M., de Nooijer, L. J., and Reichart, G.-J.: Independent impacts of calcium and carbonate ion concentration on $\mathrm{Mg}$ and $\mathrm{Sr}$ incorporation in cultured benthic foraminifera, Mar. Micropaleontol., 81, 122-130, https://doi.org/10.1016/j.marmicro.2011.08.002, 2011.

Erez, J.: The source of ions for biomineralization in foraminifera and their implications for paleoceanographic proxies, Rev. Mineral. Geochem., 54, 115-149, https://doi.org/10.2113/0540115, 2003.

Ernst, S., Janse, M., Renema, W., Kouwenhoven, T., Goudeau, M.L., and Reichart, G.-J.: Benthic foraminifera in a large IndoPacific coral reef aquarium, J. Foramin. Res., 41, 101-113, https://doi.org/10.2113/gsjfr.41.2.101, 2011.

Evans, D., Erez, J., Oron, S., and Müller, W.: Mg/Catemperature and seawater-test chemistry relationships in the shallow-dwelling large benthic foraminifera Operculina ammonoides, Geochim. Cosmochim. Ac., 148, 325-342, https://doi.org/10.1016/j.gca.2014.09.039, 2015.

Evans, D., Müller, W., and Erez, J.: Assessing foraminifera biomineralisation models through trace element data of cultures under variable seawater chemistry, Geochim. Cosmochim. Ac., 236, 198-217, https://doi.org/10.1016/j.gca.2018.02.048, 2018.

Fehrenbacher, J. S., Russell, A. D., Davis, C. V., Gagnon, A. C., Spero, H. J., Cliff, J. B., Zhu, Z., and Martin, P.: Link between light-triggered $\mathrm{Mg}$-banding and chamber formation in the planktic foraminifera Neogloboquadrina dutertrei, Nat. Commun., 8, 15441, https://doi.org/10.1038/ncomms15441, 2017.

Fernández-Díaz, L., Fernández-González, Á., and Prieto, M.: The role of sulfate groups in controlling $\mathrm{CaCO}_{3}$ polymorphism, Geochim. Cosmochim. Ac., 74, 6064-6076, https://doi.org/10.1016/j.gca.2010.08.010, 2010.

Geerken, E., de Nooijer, L. J., van Dijk, I., and Reichart, G.J.: Impact of salinity on element incorporation in two benthic foraminiferal species with contrasting magnesium contents, Biogeosciences, 15, 2205-2218, https://doi.org/10.5194/bg-152205-2018, 2018.

Geerken, E., De Nooijer, L. J., Roepert, A., Polerecky, L., King, H. E., and Reichart, G. J.: Element banding and organic linings within chamber walls of two benthic foraminifera, Sci. Rep.-UK, 9, 3598, https://doi.org/10.1038/s41598-019-40298-y, 2019.

Glas, M. S., Langer, G., and Keul, N.: Calcification acidifies the microenvironment of a benthic foraminifer (Ammonia sp.), J. Exp. Mar. Biol. Ecol., 424-425, 53-58, https://doi.org/10.1016/j.jembe.2012.05.006, 2012.
Guillard, R. R. and Ryther, J. H.: Studies of marine planktonic diatoms: I. Cyclotella Nana Hustedt, and Detonula Confervacea (CLEVE) Gran, Can. J. Microbiol., 8, 229-239, 1962.

Guillong, M., Meier, D. L., Allan, M. M., Heinrich, C. A., and Yardley, B. W.: SILLS: A MATLAB-based program for the reduction of laser ablation ICP-MS data of homogeneous materials and inclusions, Mineralogical Association of Canada Short Course Series, 40, 328-333, 2008.

Hemleben, C. H., Anderson, O. R., Berthold, W., and Spindler, M.: Calcification and chamber formation in Foraminifera-a brief overview, in: Biomineralization in lower plants and animals, edited by: Leadbeater, B. S. and Riding, R., Clarendon Press, Oxford, 237-249, 1986.

Hönisch, B. and Hemming, N. G.: Surface ocean pH response to variations in $p \mathrm{CO}_{2}$ through two full glacial cycles, Earth Planet. Sc. Lett., 236, 305-314, https://doi.org/10.1016/j.epsl.2005.04.027, 2005.

Jacob, D. E., Wirth, R., Agbaje, O. B. A., Branson, O., and Eggins, S. M.: Planktic foraminifera form their shells via metastable carbonate phases, Nature Commun., 8, 1265, https://doi.org/10.1038/s41467-017-00955-0, 2017.

Katz, A.: The interaction of magnesium with calcite during crystal growth at $25-90{ }^{\circ} \mathrm{C}$ and one atmosphere, Geochim. Cosmochim. Ac., 37, 1563-1586, https://doi.org/10.1016/00167037(73)90091-4, 1973.

Keul, N., Langer, G., de Nooijer, L. J., Nehrke, G., Reichart, G.-J., and Bijma, J.: Incorporation of uranium in benthic foraminiferal calcite reflects seawater carbonate ion concentration, Geochem. Geophy. Geosy., 14, 102-111, https://doi.org/10.1029/2012gc004330, 2013.

Kitano, Y.: The behavior of various inorganic ions in the separation of calcium carbonate from a bicarbonate solution, B. Chem. Soc. Jpn., 35, 1973-1980, 1962.

Kitano, Y., Okumura, M., and Idogaki, M.: Incorporation of sodium, chloride and sulfate with calcium carbonate, Geochem. J., 9, 7584, https://doi.org/10.2343/geochemj.9.75, 1975.

Kunioka, D., Shirai, K., Takahata, N., Sano, Y., Toyofuku, T., and Ujiie, Y.: Microdistribution of $\mathrm{Mg} / \mathrm{Ca}, \mathrm{Sr} / \mathrm{Ca}$, and $\mathrm{Ba} / \mathrm{Ca}$ ratios in Pulleniatina obliquiloculata test by using a NanoSIMS: Implication for the vital effect mechanism, Geochem. Geophy. Geosy., 7, Q12P20, https://doi.org/10.1029/2006GC001280, 2006.

Lorens, R. B.: Sr, Cd, Mn and Co distribution coefficients in calcite as a function of calcite precipitation rate, Geochim. Cosmochim. Ac., 45, 553-561, https://doi.org/10.1016/0016-7037(81)901885,1981 .

Lueker, T. J., Dickson, A. G., and Keeling, C. D.: Ocean $p \mathrm{CO}_{2}$ calculated from dissolved inorganic carbon, alkalinity, and equations for $\mathrm{K} 1$ and $\mathrm{K} 2$ : validation based on laboratory measurements of $\mathrm{CO}_{2}$ in gas and seawater at equilibrium, Mar. Chem., 70, 105-119, https://doi.org/10.1016/S0304-4203(00)00022-0, 2000.

Manoli, F. and Dalas, E.: Spontaneous precipitation of calcium carbonate in the presence of chondroitin sulfate, J. Cryst. Growth, 217, 416-421, 2000.

Mavromatis, V., Gautier, Q., Bosc, O., and Schott, J.: Kinetics of $\mathrm{Mg}$ partition and $\mathrm{Mg}$ stable isotope fractionation during its incorporation in calcite, Geochim. Cosmochim. Ac., 114, 188-203, 2013. 
Mewes, A., Langer, G., de Nooijer, L. J., Bijma, J., and Reichart, G. J.: Effect of different seawater $\mathrm{Mg}^{2+}$ concentrations on calcification in two benthic foraminifers, Mar. Micropaleontol., 113, 56-64, 2014.

Mewes, A., Langer, G., Thoms, S., Nehrke, G., Reichart, G.-J., de Nooijer, L. J., and Bijma, J.: Impact of seawater $\left[\mathrm{Ca}^{2+}\right]$ on the calcification and calcite $\mathrm{Mg} / \mathrm{Ca}$ of Amphistegina lessonii, Biogeosciences, 12, 2153-2162, https://doi.org/10.5194/bg-122153-2015, 2015.

Mezger, E. M., de Nooijer, L. J., Boer, W., Brummer, G. J. A., and Reichart, G. J.: Salinity controls on Na incorporation in Red Sea planktonic foraminifera, Paleoceanography, https://doi.org/10.1002/2016PA003052, 2016.

Mezger, E. M., Erdem, Z., Lattaud, J., van Erk, M., Schouten, S., and Reichart, G.-J.: Arabian Sea salinity and temperature changes over the last glacial cycle and impact on the oxygen minimum zone, in preparation, 2019.

Morse, J. W., Arvidson, R. S., and Lüttge, A.: Calcium carbonate formation and dissolution, Chem. Rev., 107, 342-381, https://doi.org/10.1021/cr050358j, 2007.

Mucci, A.: Growth kinetics and composition of magnesian calcite overgrowths precipitated from seawater: Quantitative influence of orthophosphate ions, Geochim. Cosmochim. Ac., 50, 22552265, https://doi.org/10.1016/0016-7037(86)90080-3, 1986.

Mucci, A.: Inlfuence of temperature on the composition of magnesian calcite overgrowths preciptated from seawater, Geochim. Cosmochim. Ac., 51, 1977-1984, https://doi.org/10.1016/00167037(87)90186-4, 1987.

Mucci, A. and Morse, J. W.: The incorporation of $\mathrm{Mg}^{2+}$ and $\mathrm{Sr}^{2+}$ into calcite overgrowths: influences of growth rate and solution composition, Geochim. Cosmochim. Ac., 47, 217-233, https://doi.org/10.1016/0016-7037(83)90135-7, 1983.

Mucci, A., Morse, J. W., and Kaminsky, M. S.: Auger spectroscopy analysis of magnesian calcite overgrowths precipitated from seawater and solutions of similar composition, Am. J. Sci., 285, 289-305, https://doi.org/10.2475/ajs.285.4.289, 1985.

Nagai, Y., Uematsu, K., Chen, C., Wani, R., Tyszka, J., and Toyofuku, T.: Weaving of biomineralization framework in rotaliid foraminifera: implications for paleoceanographic proxies, Biogeosciences, 15, 6773-6789, https://doi.org/10.5194/bg-156773-2018, 2018.

Nehrke, G., Keul, N., Langer, G., de Nooijer, L. J., Bijma, J., and Meibom, A.: A new model for biomineralization and traceelement signatures of Foraminifera tests, Biogeosciences, 10, 6759-6767, https://doi.org/10.5194/bg-10-6759-2013, 2013.

Nürnberg, D., Bijma, J., and Hemleben, C.: Assessing the reliability of magnesium in foraminiferal calcite as a proxy for water mass temperatures, Geochim. Cosmochim. Ac., 60, 803-814, https://doi.org/10.1016/0016-7037(95)00446-7, 1996.

Okai, T., Suzuki, A., Kawahata, H., Terashima, S., and Imai, N.: Preparation of a New Geological Survey of Japan Geochemical Reference Material: Coral JCp-1, Geostandard. Newslett., 26, 95-99, 2002.

Okumura, M. and Kitano, Y.: Coprecipitation of alkali metal ions with calcium carbonate, Geochim. Cosmochim. Ac., 50, 49-58, https://doi.org/10.1016/0016-7037(86)90047-5, 1986.

Paris, G., Fehrenbacher, J. S., Sessions, A. L., Spero, H. J., and Adkins, J. F.: Experimental determination of carbonate-associated sulfate $\delta^{34} \mathrm{~S}$ in planktonic foraminifera shells, Geochem. Geophy. Geosy., 15, 1452-1461, https://doi.org/10.1002/2014gc005295, 2014.

Parkhurst, D. L. and Appelo, C.: User's guide to PHREEQC (Version 2): A computer program for speciation, batch-reaction, onedimensional transport, and inverse geochemical calculations, US Geol. Surv, Denver, Colorado, 1999.

Perrin, J., Rivard, C., Vielzeuf, D., Laporte, D., Fonquernie, C., Ricolleau, A., Cotte, M., and Floquet, N.: The coordination of sulfur in synthetic and biogenic $\mathrm{Mg}$ calcites: The red coral case, Geochim. Cosmochim. Ac., 197, 226-244, https://doi.org/10.1016/j.gca.2016.10.017, 2017.

Pingitore, N. E., Meitzner, G., and Love, K. M.: Identification of sulfate in natural carbonates by X-ray absorption spectroscopy, Geochim. Cosmochim. Ac., 59, 2477-2483, https://doi.org/10.1016/0016-7037(95)00142-5, 1995.

Raja, R., Saraswati, P. K., Rogers, K., and Iwao, K.: Magnesium and strontium compositions of recent symbiontbearing benthic foraminifera, Mar. Micropaleontol., 58, 31-44, https://doi.org/10.1016/j.marmicro.2005.08.001, 2005.

Reddy, M. M. and Nancollas, G. H.: The crystallization of calcium carbonate: IV. The effect of magnesium, strontium and sulfate ions, J. Cryst. Growth, 35, 33-38, https://doi.org/10.1016/00220248(76)90240-2, 1976.

Reichart, G.-J., Jorissen, F., Anschutz, P., and Mason, P. R.: Single foraminiferal test chemistry records the marine environment Geology, 31, 355-358, 2003.

Spero, H. J., Eggins, S. M., Russell, A. D., Vetter, L., Kilburn, M. R., and Hönisch, B.: Timing and mechanism for intratest $\mathrm{Mg} / \mathrm{Ca}$ variability in a living planktic foraminifer, Earth Planet. Sc. Lett., 409, 32-42, https://doi.org/10.1016/j.epsl.2014.10.030, 2015.

Toyofuku, T., Suzuki, M., Suga, H., Sakai, S., Suzuki, A., Ishikawa, T., de Nooijer, L. J., Schiebel, R., Kawahata, H., and Kitazato, $\mathrm{H} .: \mathrm{Mg} / \mathrm{Ca}$ and $\delta^{18} \mathrm{O}$ in the brackish shallow-water benthic foraminifer Ammonia "beccarii", Mar. Micropaleontol., 78, 113-120, https://doi.org/10.1016/j.marmicro.2010.11.003, 2011.

Toyofuku, T., Matsuo, M. Y., de Nooijer, L. J., Nagai, Y., Kawada, S., Fujita, K., Reichart, G. J., Nomaki, H., Tsuchiya, M., Sakaguchi, H., and Kitazato, H.: Proton pumping accompanies calcification in foraminifera, Nat. Commun., 8, 14145, https://doi.org/10.1038/ncomms14145, 2017.

van Dijk, I., de Nooijer, L. J., Boer, W., and Reichart, G. J.: Sulfur in foraminiferal calcite as a potential proxy for seawater carbonate ion concentration, Earth Planet. Sc. Lett., 470, 64-72, https://doi.org/10.1016/j.epsl.2017.04.031, 2017a.

van Dijk, I., de Nooijer, L. J., and Reichart, G.-J.: Trends in element incorporation in hyaline and porcelaneous foraminifera as a function of $p \mathrm{CO}_{2}$, Biogeosciences, 14, 497-510, https://doi.org/10.5194/bg-14-497-2017, 2017b.

van Dijk, I., de Nooijer, L. J., Wolthers, M., and Reichart, G. J.: Impacts of $\mathrm{pH}$ and $\left[\mathrm{CO}_{3}^{2-}\right]$ on the incorporation of $\mathrm{Zn}$ in foraminiferal calcite, Geochim. Cosmochim. Ac., 197, 263-277, https://doi.org/10.1016/j.gca.2016.10.031, 2017c.

Zeebe, R. E. and Sanyal, A.: Comparison of two potential strategies of planktonic foraminifera for house building: $\mathrm{Mg}^{2+}$ or $\mathrm{H}^{+}$removal?, Geochim. Cosmochim. Ac., 66, 1159-1169, https://doi.org/10.1016/S0016-7037(01)00852-3, 2002. 